\title{
The water mite genus Recifella from Australia (Acari: Hydrachnidia: Unionicolidae)
}

\author{
Harry Smit \\ Zoological Museum, University of Amsterdam, \\ Plantage Middenlaan 64, 1018 DH Amsterdam, The Netherlands \\ e-mail: smit.hawolmail.nl
}

\begin{abstract}
Eight new Recifella species are described: $R$. crassipalpis, $R$. hyporheica, $R$. emma, R. kakadu, R. kimberleyensis, $R$. ligulifera, $R$. ornata and $R$. pseudoszalayi. One of these, $R$. hyporheica, is the first reported hyporheic species of the genus. Recifella pectinata $S$ mit is synonymized with $R$. baltoona Cook. New descriptions are provided for the females of $R$. agnosta Cook, $R$. flagellata Cook and $R$. pinguipalpifera Wiles, the latter reported for the first time for Australia. Many new records are given, especially for the Northern Territory and Western Australia, and a key is given for the Australian species.
\end{abstract}

\section{INTRODUCTION}

The genus Recifella is very similar to Koenikea, and was described as a subgenus of the latter (Viets 1935). Cook (1980) elevated Recifella to a full genus based on the pronounced sexual dimorphism of the male fourth leg and the dorsal shield bearing three or four pairs of glandularia. Moreover, the apodemes of the anterior coxal plates extend onto the third coxal plates. Recifella is widespread, and occurs in Australia, New Guinea, New Caledonia and the New World. To date, six subgenera have been described, i.e. Recifella Viets, Monokoenikea Lundblad, Eorecifella Cook, Recitellopsis Cook, Recifellida Cook and Vietsiella Cramer and Cook. From Australia only Eorecifella and Recifellida are known (Cook 1986; Harvey 1998). The latter subgenus is confined to the Australian faunal region, and has been found in Australia and New Caledonia (Smit 2002). Most females of the genus lack striking species-specific characters, only those females with special characters, e.g. $R$. flagellata or $R$. crassipalpis sp. nov. are easy to identify. Therefore, assignment is usually based on the accompanying males.

Within Australia, 14 Recifella species are currently known. Most species are known from Queensland and New South Wales, and thus far no species have been reported from Western Australia, Northern Territory, Victoria and South Australia. In this paper eight new species are described while one species is synonymized, bringing the total number of Recifella species known from Australia to 21. Many new distribution records are given, especially for the Northern Territory and Western Australia, and a key is given for the Australian species of the genus.

\section{MATERIAL AND METHODS}

Unless stated otherwise, all material has been collected by the author. The hyporheic collections have been conducted with a modified Bou-Rouch pump (see Boulton et al. 1992). Specimens are lodged in the Australian Museum, Sydney (AMS), Museum and Art Gallery of the Northem Territory, Darwin (NTM), Queensland Museum, Brisbane (QM), Western Australian Museum, Perth (WAM), and Zoological Museum of the University of Amsterdam (ZMAN). Non-type material is deposited in the Zoological Museum of the University of Amsterdam and the Western Australian Museum, Perth.

The following abbreviations have been used: PIPV for palp segments 1-5; IV-leg-4-6 for the fourth to sixth segments of fourth leg; a.s.l. above sea level.

Range measurements given comprise all specimens mentioned in the material examined. All species have dorsal and ventral shields, and this is not repeated in the text. All but one Australian species have the postocularia and glandularia 2 (sensu Lundblad 1943) fused with the dorsal portion of the ventral shield. This is also not repeated in the text. In the systematics section, species are presented alphabetically within subgenera.

\section{SYSTEMATICS}

\section{Family Unionicolidae Oudemans}

\section{Recifella Viets}

Koenikea (Recifella) K. Viets, 1935: 276.

Recifella K. Viets: Cook, 1980: 196. 


\section{Type species}

Koenikea (Recifella) laminipes K. Viets, 1935, by original designation.

\section{Koenikea (Eorecifella) Cook}

Eorecifella Cook, 1980: 201.

\section{Type species}

Koenikea (Koenikea) balteata Lundblad, 1943, by original designation.

\section{Diagnosis}

Male without pronounced sexual dimorphism of fourth leg.

\section{Recifella (Eorecifella) australica Cook}

Recifella (Eorecifella) australica Cook, 1986: 171; Harvey, 1998: 142.

\section{Material examined}

Australia: Tasmania: $14 q$, old river branch Coal River, N. of Richmond, 17 October 1997; 6 \%, reservoir of Darlington, Maria Island National Park, 18 October 1997; 3 \%, Apsley River at crossing with Tasmanian Highway, 19 October 1997; 7 \% , Douglas River at crossing with Tasmanian Highway, 20 October 1997; 3 q, swamp $12 \mathrm{~km} \mathrm{~S}$. of Gladstone, at crossing with road B82, 20 October 1997. Victoria: 1 ठ․ Shipwreck Creek at Mallacoota, Croajingolong National Park, 23 October 1997; 1 ㅇ, unnamed creek $4.5 \mathrm{~km}$ E. of Croajingolong National Park, 23 October 1997; 2 \&, Double Creek, Croajingolong National Park, 23 October 1997; 1 \%, Lower Stony Creek, Brisbane Ranges National Park, 27 September 1997. New South Wales: 2 , Bola Creek at Bola Creek Picnic Area, Royal National Park, 8 November 2001; 20,3 o, Wheeny Creek at crossing with Comleroy Road, Wollemi National Park, 1 December 2003; 2 , 3 \%, Shoalhaven River at Berlang Camping Area, Deua National Park, $706 \mathrm{~m}$ a.s.l., $35^{\circ} 43.487^{\prime} \mathrm{S}$, 149³8.911'E, 14 December 2003.

\section{Remarks}

Previously reported from Tasmania, New South Wales and Queensland. Therefore the first record from Victoria comes as no surprise.

\section{Recifella (Eorecifella) crassipalpis sp. nov.} Figures 1-7

\section{Material examined}

Holotype

Australia: Western Australia: $\delta$, stream El Questro Gorge, El Questro Station, The Kimberley, 15 September 1998 (WAM T73161).

\section{Paratypes}

Australia: Western Australia: 1 , same data as holotype (WAM T79681); Northern Territory: 4 ㅇ (NTM A003760, A003761, A003762), pools upstream of Waterfall Creek, Kakadu National Park, $13^{\circ} 25^{\prime}$ S, $132^{\circ} 25^{\prime}$ E, 25 July 1994; 6 \& (ZMAN TYPE ACAR.0005.1-6), Radon Springs, Kakadu National Park, 19 July 1994 (ZMAN).

\section{Diagnosis}

Palp stocky, PII with a large heavy seta on a large tubercle, PIV with a large setal tubercle.

\section{Description}

Male

Body 526 long and 504 wide. Dorsal shield completely separated from ventral shield and with three pairs of glandularia, 462 long and 413 wide. First coxal plates extending slightly beyond anterior margin of idiosoma. Apodemes of anterior coxal plates extending to anterior part of third coxal plates. Gonopore 72 long. Genital plates with numerous ( $>25$ pairs) acetabula. Lengths of PI-PV: $12,82,47,54,26$. Palp very stocky, PI short, PII with a large tubercle with a heavy seta, PIV short with a large setal tubercle, PV with heavy terminal setae. Palp with a reticulate pattern. Lengths of I-leg-4-6: 120, 142, 144. Lengths of IV-leg-4-6: 142, 190, 180. IV-leg-5 with five pectinate setae (not visible in illustrated leg due to position in the slide), IV-leg-4 and III-leg-5 with four pectinate setae. III-leg-3 with one swimming seta, III-leg-4 with two, III-leg-5 with three, IV-leg-3 with one, IV-leg-4 with five and IV-leg-5 with three swimming setae.

\section{Female}

Body 697 (680) long and 644 (591-599) wide. Dorsal shield 648 long and 571 wide, with three pairs of glandularia, the posterior pair on small tubercles. Dorsal furrow without glandularia. Anterior coxal plates not extending beyond anterior body margin. Apodemes of anterior coxal plates short, not extending to posterior margin of third coxal plates. Gonopore 125 long. Genital field with 37-38 pairs of acetabula. Lengths of PI-PV: 12, 129, $62,80,32$. Lengths of I-leg-4-6: 142, 162, 140. Lengths of IV-leg-4-6: 168, 184, 198. Swimming setae on the following leg segments: III-leg-4 (2), III-leg-5 (3), IV-leg-4 (5), IV-leg-5 (3). I-leg-5 with two rudimentary swimming setae, II-leg-4 and IIleg-5 with one rudimentary swimming seta.

\section{Etymology}

This species is named after its unusual stocky palp.

\section{Remarks}

The new species is close to Recifella (Eorecifella) 

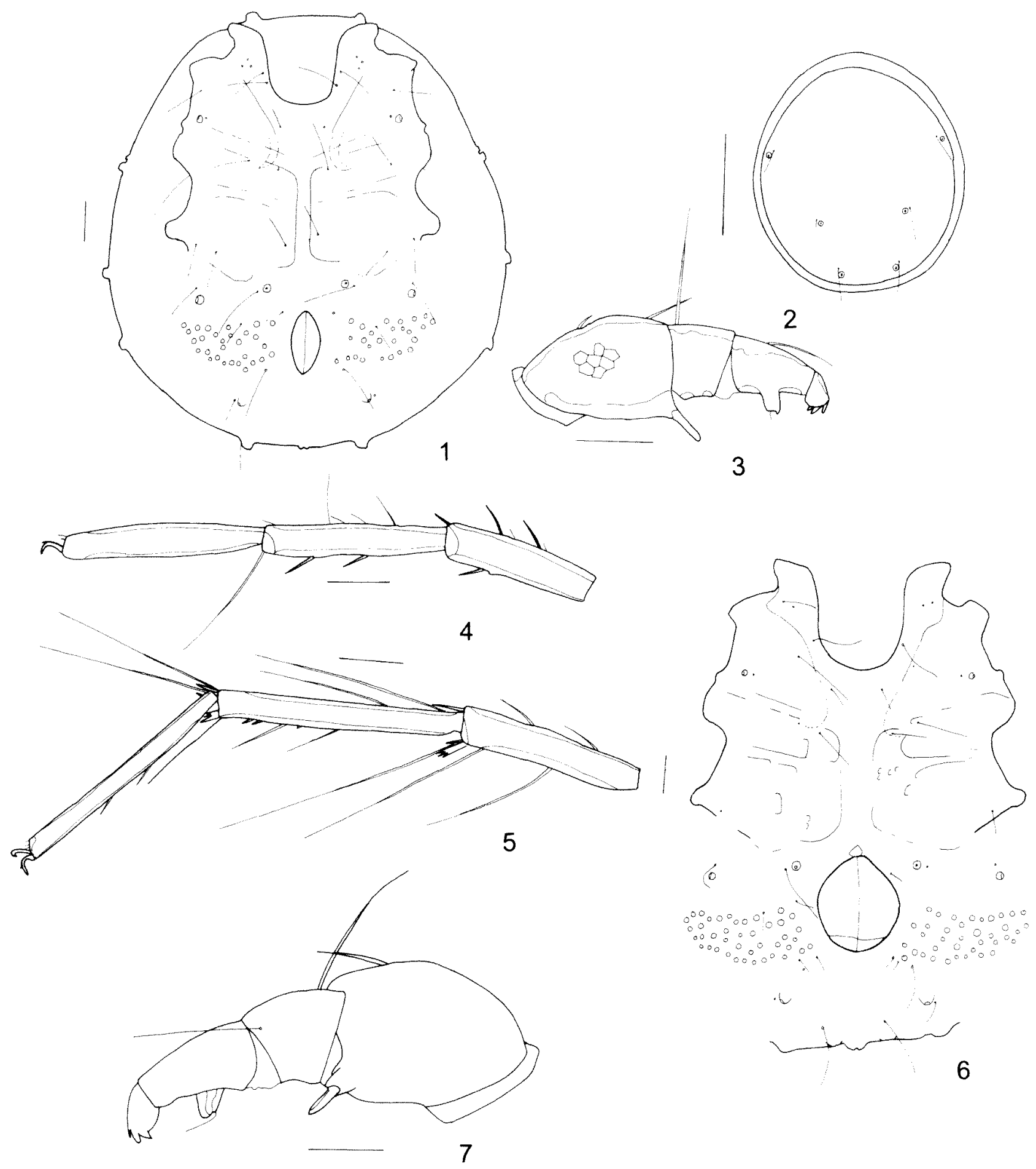

Figures 1-7 Recifella crassipalpis sp. nov.: 1-5, holotype male: 1, idiosoma, ventral view; 2, dorsal view; 3, left palp; 4, I-leg-4-6; 5, IV-leg-4-6; 6-7, paratype female: 6, idiosoma, ventral view; 7 right palp. Scale lines: 50 um (Figures 1, 3-7), $200 \mu \mathrm{m}$ (Figure 2).

pinguipalpifera Wiles from New Guinea (Wiles 1997). However, PII of this species lacks a tubercle, the heavy seta of PII is longer, PIV is less stocky and PIV has two smaller setal tubercles.

\section{Recifella (Eorecifella) flagellata Cook}

Recifella (Eorecifella) flagellata Cook, 1986: 170; Harvey, 1998: 142.

\section{Material examined}

Australia: New South Wales: 5 o, 14 , Waterfall Creek at Gunjulla Flat, Royal National Park, 8 November 2001; 1 j, 4 \%, Bola Creek at Bola Creek Picnic Area, Royal National Park, 8 November 2001; 2 6. Moonmerri Creek, Nymboi-Binderay National Park, alt. $446 \mathrm{~m}$ a.s.l., $30^{\circ} 11.406^{\prime} \mathrm{S}, 152^{\circ} 41.436 \mathrm{E}, 9$ November 2003; 1 \&, Way Way Creek, Yarriabinni National Park, 23 November 2003. Queensland: 18 
o, $31 q$, Tim Shea Creek near Tim Shea Falls, Bunya Mountains National Park, 18 November 2003; 1 \%, 4 \&, Barkers Creek at Little Falls, Bunya Mountains National Park, 19 November 2003; 1 \%, Saddle-tree Creek, Bunya Mountains National Park, 19 November 2003.

\section{Description}

Male

Idiosoma 551-616 long and 478-543 wide (holotype 456 long and 395 wide). IV-leg-5 with 3-4 setae (holotype three) and one distal pectinate seta, IV-leg-6 with 2-3 setae (holotype with two setae).

\section{Female}

Idiosoma 680 (624-721) long and 583 (539-632) wide. Dorsal shield complete with three pairs of glandularia. No glandularia lying in the dorsal furrow. First coxal plates extending well beyond anterior margin of idiosoma. Apodemes of anterior coxal plates extending to posterior margin of third coxal plates. Genital field with 16 pairs of acetabula. Gonopore 108 long and 116 wide. Lengths of PI-PV: $18,74,40,90,36$; palp as in male. Lengths of I-leg-46: 208, 182, 146. Lengths of IV-leg-4-6: 154, 186, 172. II-leg-4 with one swimming seta, III-and IV-leg-3 with one swimming seta, III- and IV-leg-4 with three swimming setae, III-leg-5 with two swimming setae and IV-leg-5 with five swimming setae.

\section{Remarks}

The measurements given here are made from two populations: Tim Shea Creek (Queensland) and Waterfall Creek (New South Wales). The species was only known from the holotype male, which was described from Queensland. The holotype is smaller than the male specimens from this study, but they agree well in all characters. The female is described here for the first time. As the female shows no obvious species-specific characters (except the long dorsodistal seta of PIV), no illustration is provided.

\section{Recifella (Eorecifella) hyporheica sp. nov.} Figures 8-14

\section{Material examined}

Holotype

Australia: New South Wales: $\delta$, hyporheic of Carters Creek at crossing with Western Distributor Road, $35^{\circ} 30.914^{\prime} \mathrm{S}, 150^{\circ} 03.546^{\prime} \mathrm{E}$, altitude $187 \mathrm{~m}$ a.s.l., 16 December 2003 (AMS KS 94672).

\section{Paratypes}

Australia: New South Wales: 1 , same data as holotype (AMS KS 94673); 1 \%, same data as holotype (ZMAN TYPE ACAR.0006.1); 1 ;, hyporheic of Cabbage Tree Creek at crossing with Kings Highway, $35^{\circ} 34.367^{\prime} \mathrm{S}, 150^{\circ} 02.537^{\prime} \mathrm{E}$, altitude $260 \mathrm{~m}$ a.s.l., 16 December 2003 (ZMAN TYPE ACAR.0006.2). Queensland: 1 \& (QM S73410), Dalrymple Creek, hyporheic, Goomburra Forest Reserve, Queensland, 2758.781'S, $152^{\circ} 20.621^{\prime} \mathrm{E}$, altitude $690 \mathrm{~m}, 5$ November 2005; 1 \&, same data (ZMAN ACAR.0006.3).

\section{Diagnosis}

Postocularia and glandularia 2 (sensu Lundblad 1943) in dorsal furrow.

\section{Description}

Male

Idiosoma 664 long and 632 wide. Dorsal shield 618 long and 559 wide, strongly convex with three pairs of acetabula, all near lateral margin. Dorsal shield completely separated from ventral shield. Postocularia, glandularia 2 (sensu Lundblad 1943) and a pair of glandularia posteriorly of dorsal shield in dorsal furrow. Eyes present. Anterior coxal plates extending beyond anterior idiosoma margin. Apodemes of anterior coxal plates extending beyond the middle of third coxal plates. Tubercles associated with glandularia small. Gonopore 82 long. Genital field indistinct with approximately 20 pairs of acetabula. Lengths of PIPV: $24,89,37,82,30$. Lengths of I-leg-4-6: 126, 130, 142; heavy setae relatively short. Lengths of IV-leg4-6: 158, 196, 181. IV-leg-5 with a heavy distal seta and three more proximally located heavy setae, all with small pectinations. Also heavy seta of III-leg-5 with small pectinations. Only rudimentary swimming setae present: III-leg-4 with one, III-leg-5 with two, IV-leg-4 with three and IV-leg-5 with two such setae. Excretory pore terminal.

\section{Female}

Idiosoma 786 (624-818) long and 778 (585-786) wide. Dorsal shield 747 (575-747) long and 713 (527-713) wide, strongly convex with three pairs of acetabula, all near lateral margin. Dorsal shield completely separated from ventral shield. Postocularia, glandularia 2 (sensu Lundblad 1943) and a pair of glandularia posteriorly of dorsal shield in dorsal furrow. Eyes present. Anterior coxal plates extending beyond anterior idiosoma margin. Apodemes of anterior coxal plates extending to the middle of third coxal plates. Tubercles associated with glandularia small. Gonopore 144 long. Genital field indistinct with approximately 12-18 pairs of acetabula. Lengths of PI-PV: 23, 102, 36, 88, 36; palp as in male. Lengths of I-leg-4-6: 149, 153, 154; heavy setae of first leg relatively long. Lengths of IV-leg-4-6: 170, 214, 188. Swimming setae as in male. 

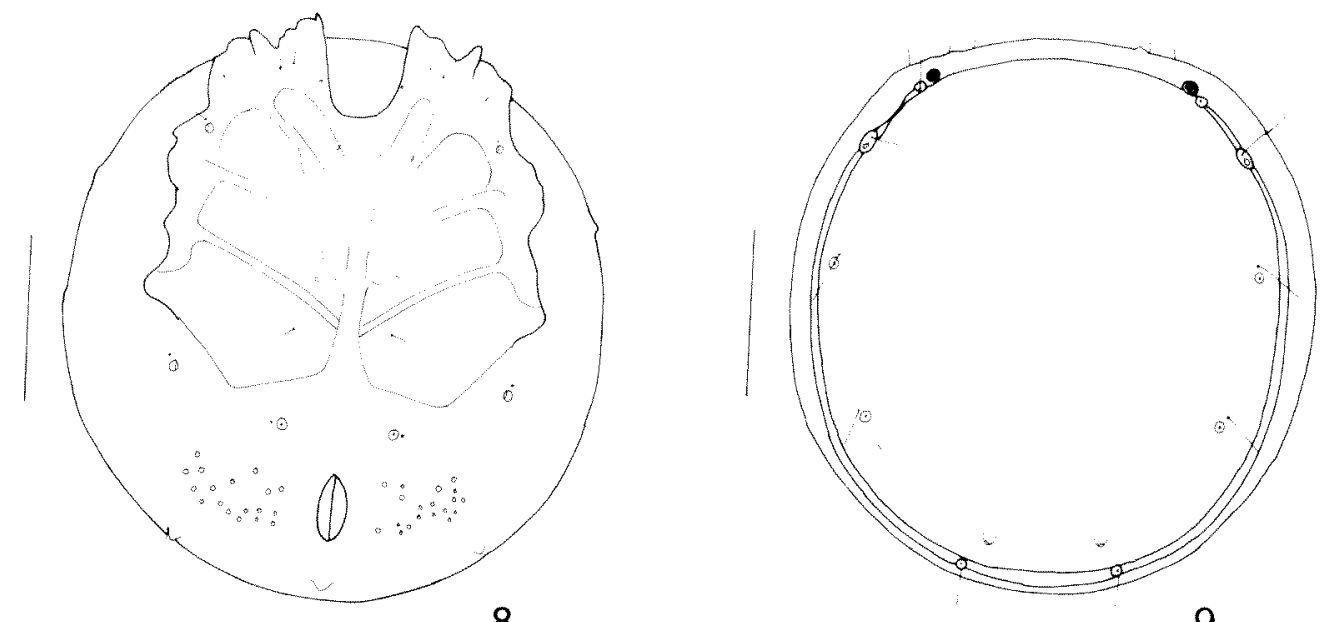

8
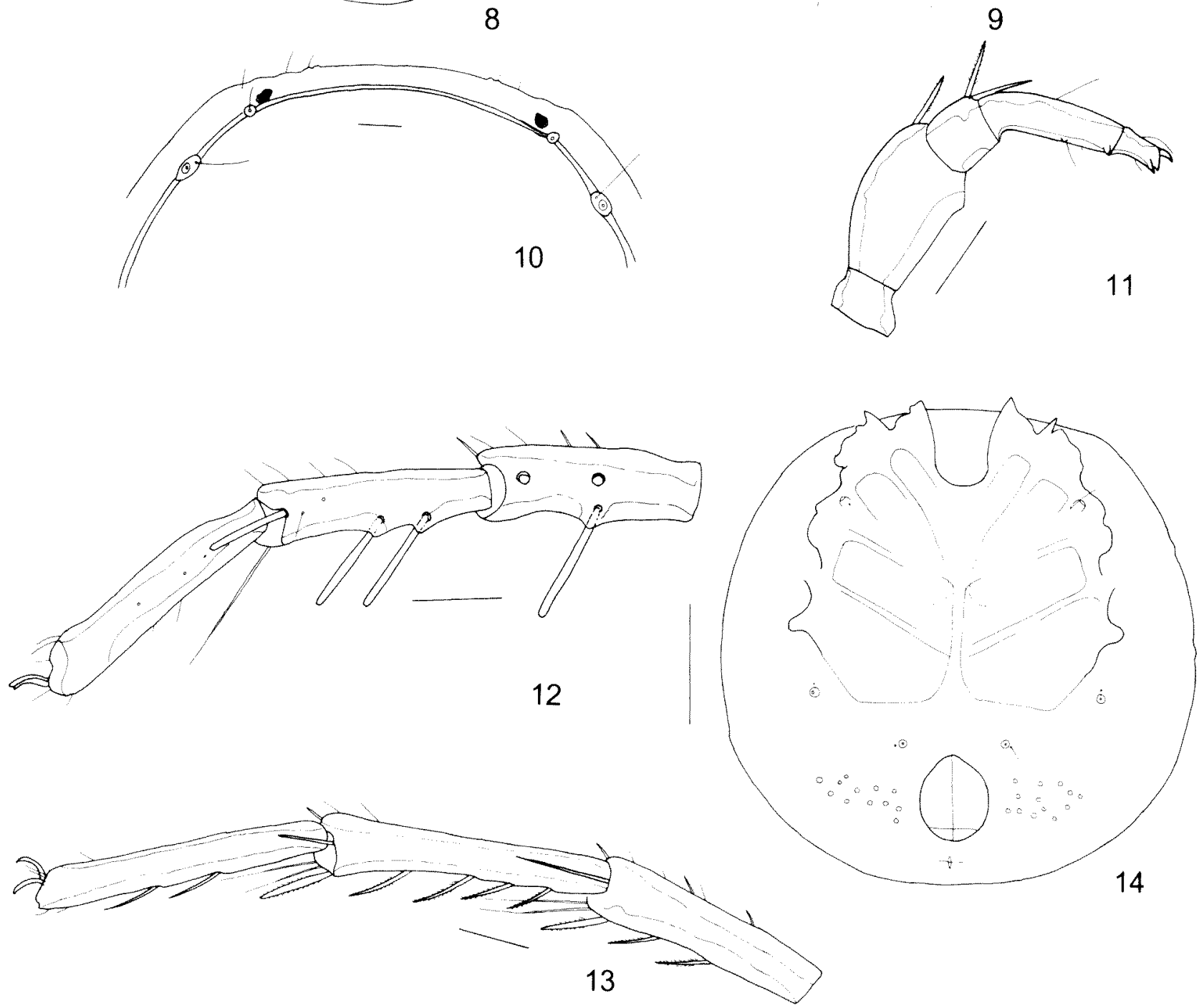

Figures 8-14 Recifella hyporheica sp. nov.: 8-13, holotype male: 8, idiosoma, ventral view; 9, idiosoma, dorsal view; 10, idiosoma, detail of anterior part of dorsum; 11, left palp; 12, I-leg-4-6; 13, IV-leg-4-6; 14, paratype female: 14 idiosoma, ventral view. Scale lines: $50 \mu \mathrm{m}$ (Figures 10-13), $200 \mu \mathrm{m}$ (Figures 8-9, 14).

\section{Etymology}

This species is named for its occurrence in the hyporheos.

\section{Remarks}

This is the first known Recifella species collected in a hyporheic habitat, as no records have been published previously from this habitat. As all records of the new species are from hyporheic habitats, it is very likely an obligatory hyporheic species. The new species differs from all other Australian species in the presence of postocularia 
and glandularia 2 in the dorsal furrow. Within the subgenus Eorecifella shifting of dorsal glandularia has occurred. In some Neotropical species of the subgenus the same configuration as in the new species from Australia can be found. In other Neotropical species, however, glandularia 2 are fused with the dorsal portion of the ventral shield, while the postocularia are lying free in the dorsal furrow.

\section{Recifella (Eorecifella) pinguipalpifera Wiles Figures 15-16}

Recifella pinguipalpifera Wiles, 1997: 390.

\section{Material examined}

Australia: Queensland: $1 \delta$, Chili Creek, Iron Range National Park, 7 September 2000; 1 \$, 1 \%, 2 nymphs, West Claudie River, Iron Range National Park, 7 September 2000; 1 o, 1 \%, Packers Creek, Iron Range National Park, 9 September 2000.

\section{Description}

Male

Idiosoma 802 (753-773) long and 711 (688-713) wide, dorsal shield 717 long and 608 wide. Palp as described by Wiles (1997), but one of the palps of the male from Packers Creek with PII with an additional smaller heavy seta. PV with a long seta. Genital plates with approximately 30 pairs of acetabula. I-leg-2-4 thickened. The number of swimming setae is as follows: I-leg-4 with one swimming seta, I-leg-5 with two rudimentary swimming setae, II-leg- 4 with one, II-leg-5 with three, III-leg-3 with one, III-leg-4 with 3, III-leg-5 with three, IV-leg-3 with one, IV-leg- 4 with three and IV-leg-5 with five (three + two) swimming setae. Legs with a reticulate pattern, especially distinct in I- and II-leg.

\section{Female}

Idiosoma 891 (834) long and 770 (738) wide. Dorsal shield complete with three pairs of glandularia. Dorsal furrow without glandularia. Dorsal shield 786 long and 667 wide. First coxal plates pointed and extending beyond anterior idiosoma margin. Apodemes of anterior coxal plates extending to posterior margin of third coxal plates. Medial margin of third coxal plates much shorter than medial margin of fourth coxal plates. Gonopore 137 long. Genital field with numerous (> 30 pairs) acetabula. Lengths of PI-PV: 14, 130, 54, 92, 44; palp as in male. Lengths of I-leg-4-6: 170, 150, 122; I-leg-2-4 thickened. Lengths of IV-leg-4-6: $196,240,206$. Swimming setae as in male. Excretory pore terminal.

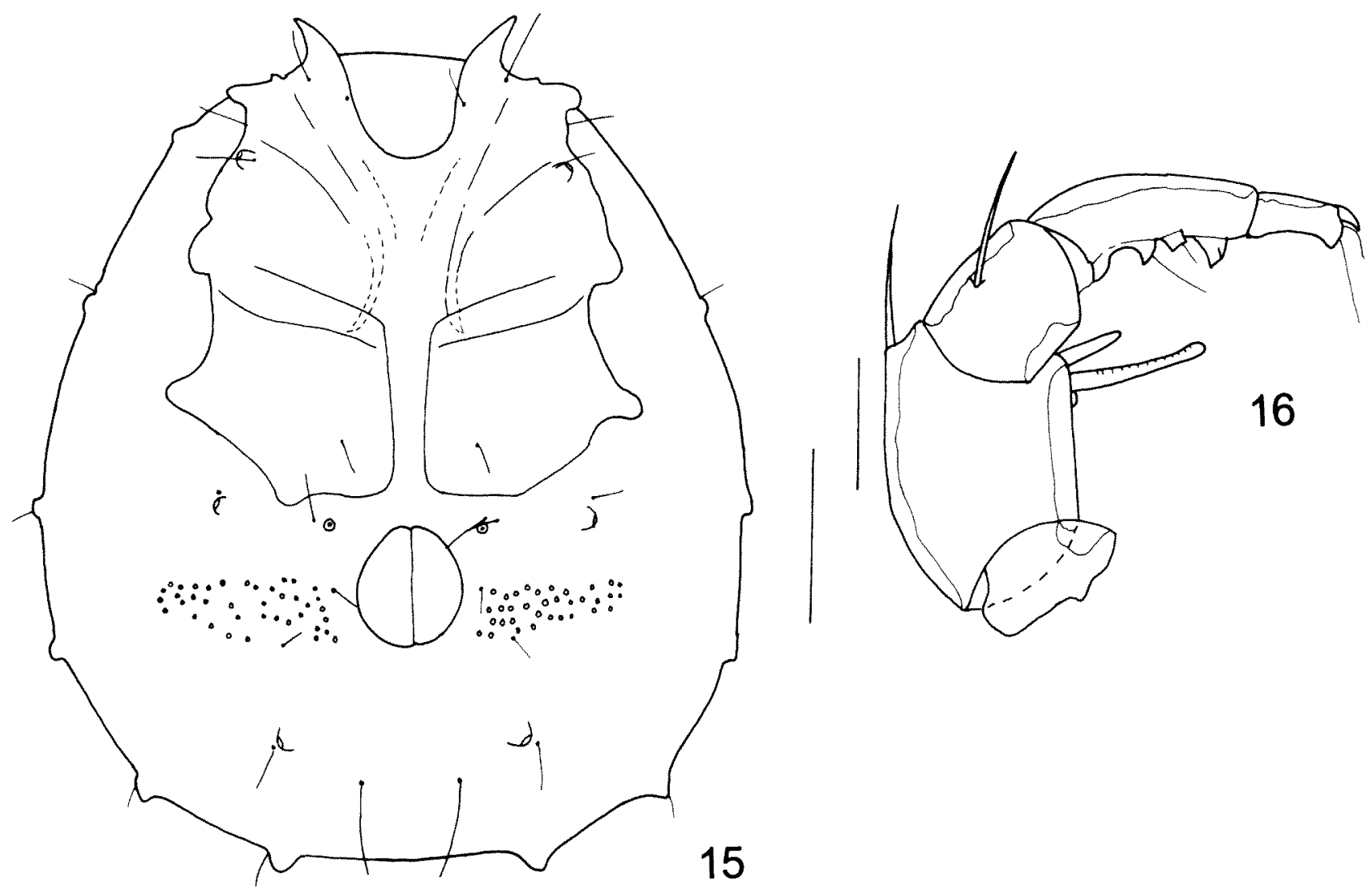

Figures 15-16 Recifella pinguipalpifera Wiles: female: 15, idiosoma, ventral view; 16, aberrant right palp. Scale lines: $200 \mu \mathrm{m}$ (Figure 15), $50 \mu \mathrm{m}$ (Figure 16). 


\section{Remarks}

The species was previously known from the holotype male described from New Guinea. It is therefore reported here for the first time for Australia. There are a number of differences between the holotype male and males from this study. The additional heavy seta of the male from Packers Creek is not found in the holotype, but this probably refers to an aberrant palp. Moreover, the long seta of PV is also not mentioned by Wiles (1997). Males from this study have many fewer acetabula (30 versus 100 in the holotype). The number of swimming setae is also different. However, given its unusual palp, the Australian specimens must very likely be assigned to this species. The female is described here for the first time.

\section{Recifella (Recifellida) Cook}

Recifella (Recifellida) Cook, 1986: 168.

\section{Type species}

Recifella (Recifellida) bifida Cook, 1986, by original designation.

\section{Diagnosis}

Fourth leg of male and to a lesser extent third leg of male modified. IV-leg-5 of male longer than IVleg- 6 of male and tending to be curved. IV-leg-5 of male with three ventral setae exhibiting varying degrees of modifications.

\section{Recifella (Recifellida) agnosta Cook}

Recifella (Recifellida) agnosta Cook, 1986: 181; Harvey, 1998: 142.

\section{Material examined}

Australia: Queensland: $1 \delta, 4$ \&, Lacey Creek, Mission Beach, 17 September 2000.

\section{Description}

Female

Idiosoma 632 (612-656) long and 526 (510-543) wide. Dorsal shield with three pairs of glandularia, 530 long and 470 wide. One pair of glandularia in the dorsal furrow posteriorly of dorsal shield. First coxal plates extending to anterior idiosoma margin. Apodemes of anterior coxal plates reaching beyond middle of third coxal plates. Genital field with numerous (approximately 20 pairs) acetabula. Gonopore 110 long. Lengths of PI-PV: 22, 91, 48, 101, 20; palp as in male. Lengths of I-leg-4-6: 150, 156, 146. Lengths of IV-leg-4-6: 164, 200, 186. Swimming setae as given for male. Excretory pore not terminal as in male, but located some distance from posterior idiosoma margin.

\section{Remarks}

Thus far, only the male had been described (Cook 1986). As the female shows no clear species-specific characters, only a description is given. The species has only been found in Queensland.

\section{Recifella (Recifellida) baltoona Cook}

Recifella (Recifellida) baltoona Cook, 1986: 178; Harvey, 1998: 142.

Recifella (Recifellida) pectinata Smit, 1992: 103. New synonymy.

\section{Material examined}

Holotype of Recifella pectinata

Australia: Queensland: ठ, lake near Eungella Dam, $10 \mathrm{~km} \mathrm{W.} \mathrm{of} \mathrm{Eungella,} \mathrm{Queensland,} 28$ July 1989 (QM S21124).

\section{Other material}

Australia: Queensland: 1 d, 1 \&, Fitzroy River, 15 March 1983, A.P. Mackay; 1 o, 1 \&, Fitzroy River, Rockhampton, 29 March 1983, A.P. Mackay; 1 f , Fitzroy River, Yaamba, 11 March 1984, A.P. Mackay; 1 o, 3 \&, Crediton Creek, Eungella National Park, 18 September 2000. Northern Territory: 1 d, 1 , Douglas River at Douglas Hot Springs, 1 August 1994. Western Australia: 1 d, pool Manning Gorge Falls, The Kimberley, 13 September 1998; 2 J, Miner's Pool, Drysdale River Homestead, The Kimberley, 14 September 1998; 1 ¿, pool Amalia Gorge, El Questro Station, The Kimberley, 16 September 1998; 8 \%, 11 옹 pool Valentine Springs, W. of Kununurra, 18 September 1998 (WAM T 66730); 1 o, plunge pool Cathedral Gorge, Purnululu National Park, 24 September 1998; 1 t, 5 \&, pool Sawpit Gorge, S. of Halls Creek, 25 September 1998; 10 , pools in creek at Old Halls Creek, S. of Halls Creek, 26 September 1998; $1 \delta$, pool W. of Tunnel Creek, Tunnel Creek National Park, 30 September 1998.

\section{Remarks}

This species has been previously reported from Tasmania, New South Wales and Queensland, and reported here for the first time from the Northern Territory and Western Australia. Recifella pectinata described by Smit (1992) from Queensland must be considered a synonym of $R$. baltoona. Although I noted the similarity between the two species, I overlooked the short heavy setae of the third leg, which are characteristic for $R$. baltoona. Moreover, $R$. baltoona also has a heavy distal pectinate seta on IV-leg-4.

\section{Recifella (Recifellida) bifida Cook}

Recifella (Recifellida) bifida Cook, 1986: 179; Harvey, 1998: 142. 
Material examined

Australia: Queensland: $1 \delta, 3 q$, billabong $W$. of Wenlock River, near crossing with road to Iron Range National Park, 10 September 2000; 1 \%, 8 , Twin Falls, Cape York Peninsula, 11 September 2000. Northern Territory: $9 \delta, 24 \%$, billabong Nourlangie Creek, Kakadu National Park, 20 July 1994; 1 oे, Mardugal Billabong, Kakadu National Park, 21 July 1994; 1 o, 3 q, pools upstream of Waterfall Creek, Kakadu National Park, 25 July 1994; 2 8, 3 ㅇ, Lily Pond Falls, Katherine Gorge National Park, 27 July 1994. Western Australia: 4 o, pool Galvans Gorge, The Kimberley, 12 September 1998; 3 \%, 4 의, plunge pool Adcock Gorge, The Kimberley, 12 September 1998 (WAM T66731); $1 \delta$, pool downstream of Manning Gorge, at campground, The Kimberley, 12 September 1998; 5 o, Miner's Pool, Drysdale River Homestead, The Kimberley, 14 September 1998; 6 d, pool Amalia Gorge, El Questro Station, The Kimberley, 16 September 1998; 1 §, 3 ㅇ, Zebedee Springs (hot springs), El Questro Station, The Kimberley, 16 September 1998 (WAM T66732); 14 oे, 16 \%, Middle Springs W. of Kununurra, 18 September 1998.

\section{Remarks}

Previously only known from the type locality in Queensland, and reported here for the first time from the Northern Territory and Western Australia.

\section{Recifella (Recifellida) doomba Cook}

Recifella (Recifellida) doomba Cook, 1986: 174; Harvey, 1998: 142.

\section{Material examined}

Australia: Northern Territory: $3 \delta$, waterhole Ormiston Gorge, Ormiston Gorge National Park, 6 August 1994. Queensland: 1 \&ै, Nankin Creek, Rockhampton, 6 February 1982, A.P. Mackay.

\section{Remarks}

Previously reported from Queensland and New South Wales, and here reported for the first time for the Northern Territory.

\section{Recifella (Recifellida) emma sp. nov.} Figures 17-23

\section{Material examined}

Holotype

Australia: Western Australia: $\delta$, plunge pool Emma Gorge, The Kimberley, 16 September 1998 (WAM T73162).

\section{Diagnosis}

III-leg-5 of male with unusual distal heavy seta, dorsal margin with only one tooth, ventral margin with four teeth.

\section{Description}

Male

Idiosoma somewhat rectangular, 553 long and 459 wide. Dorsal shield 543 long and 408 wide with four pairs of glandularia. Dorsal shield lightly fused posteriorly with ventral shield. Apodemes of anterior coxal plates reaching to posterior margin of third coxal plates. Gonopore relatively wide, 84 long and 36 wide. Genital plates with numerous ( $>35$ pairs) acetabula. Lengths of PI-PV: 26, 112, 48, 94, 36. Ventral margin of PII slightly convex, PV with heavy distal setae. Lengths of I-leg-4-6: 109, 132, 130. Lengths of IV-leg-4-6: 179, 210, 136. III-leg-5 with an unusual distal seta, with one margin with only one tooth, the other margin with four teeth. Ventral margin of III-leg-5 with two curved setae with very fine pectinations, III-leg- 4 with one seta with fine pectinations. IV-leg-5 with three small setae with large pectinations in proximal half. The two most proximal of these setae located next to each other, and therefore in lateral view only two of these setae are visible. III-leg-3 with one swimming seta, III-leg-4 and -5 with three swimming setae, IV-leg-3 with one swimming seta, IV-leg-4 with five swimming setae and IV-leg-5 with three swimming setae. First and second leg with swimming setae reduced in length.

Female

Unknown.

\section{Etymology}

This species is named after the type locality and is a noun in apposition.

\section{Remarks}

The unusual distal seta of III-leg-5 will make identification of the new species easy. Recifella colorata (K.O. Viets), known from the female only, has PV also with heavy setae. However, all three distal setae of PV of $R$. colorata are equally spaced, while in the new species the dorsal seta is distanced from the two ventral setae.

\section{Recifella (Recifellida) kakadu sp. nov.} Figures 24-29

\section{Material examined}

Holotype

Australia: Northern Territory: $\delta$, Baboalba Springs (Gubarra), Kakadu National Park, 12 52 'S, $132^{\circ} 15^{\prime} \mathrm{E}, 20$ July 1994 (NTM A003765). 


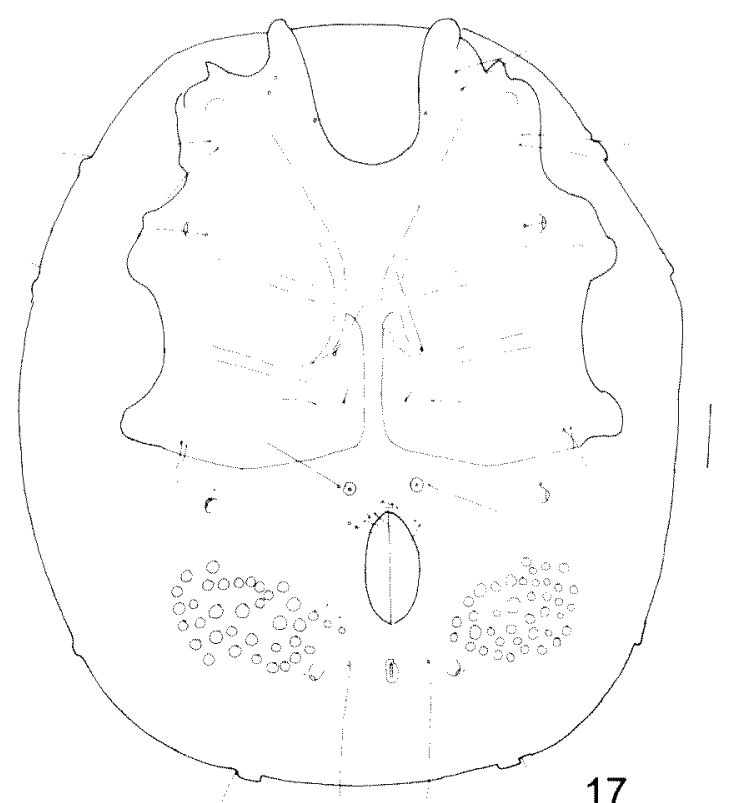

17

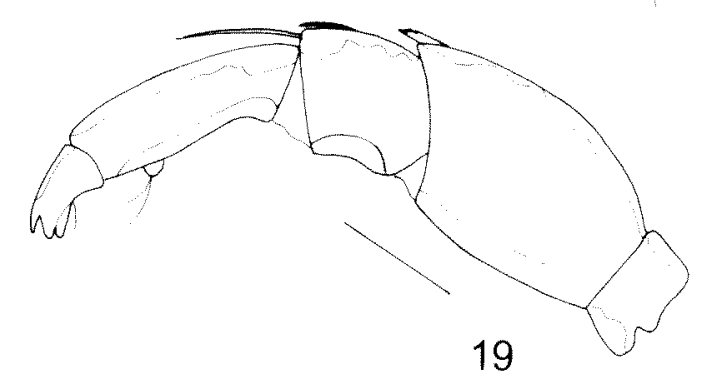

18
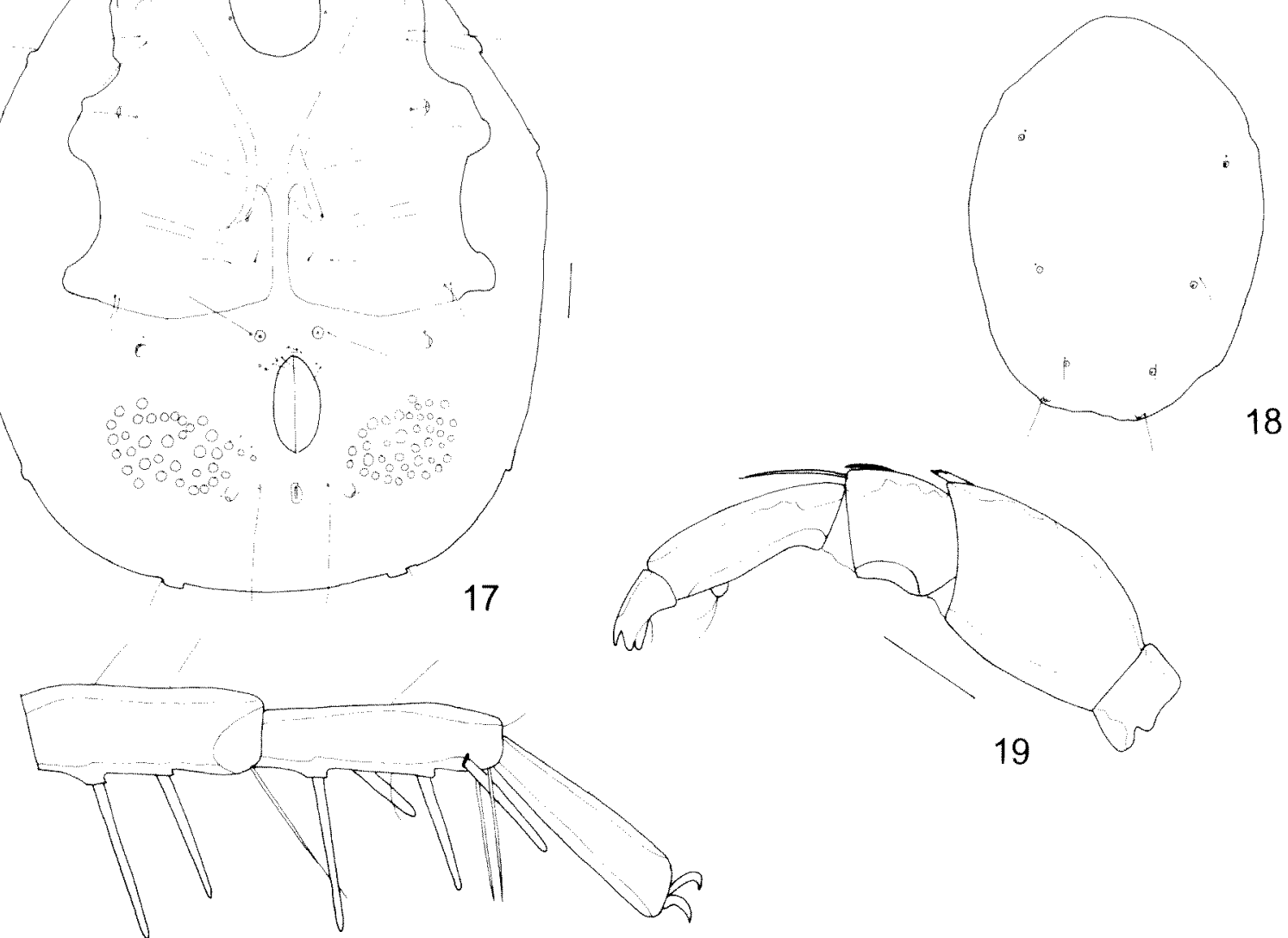

20

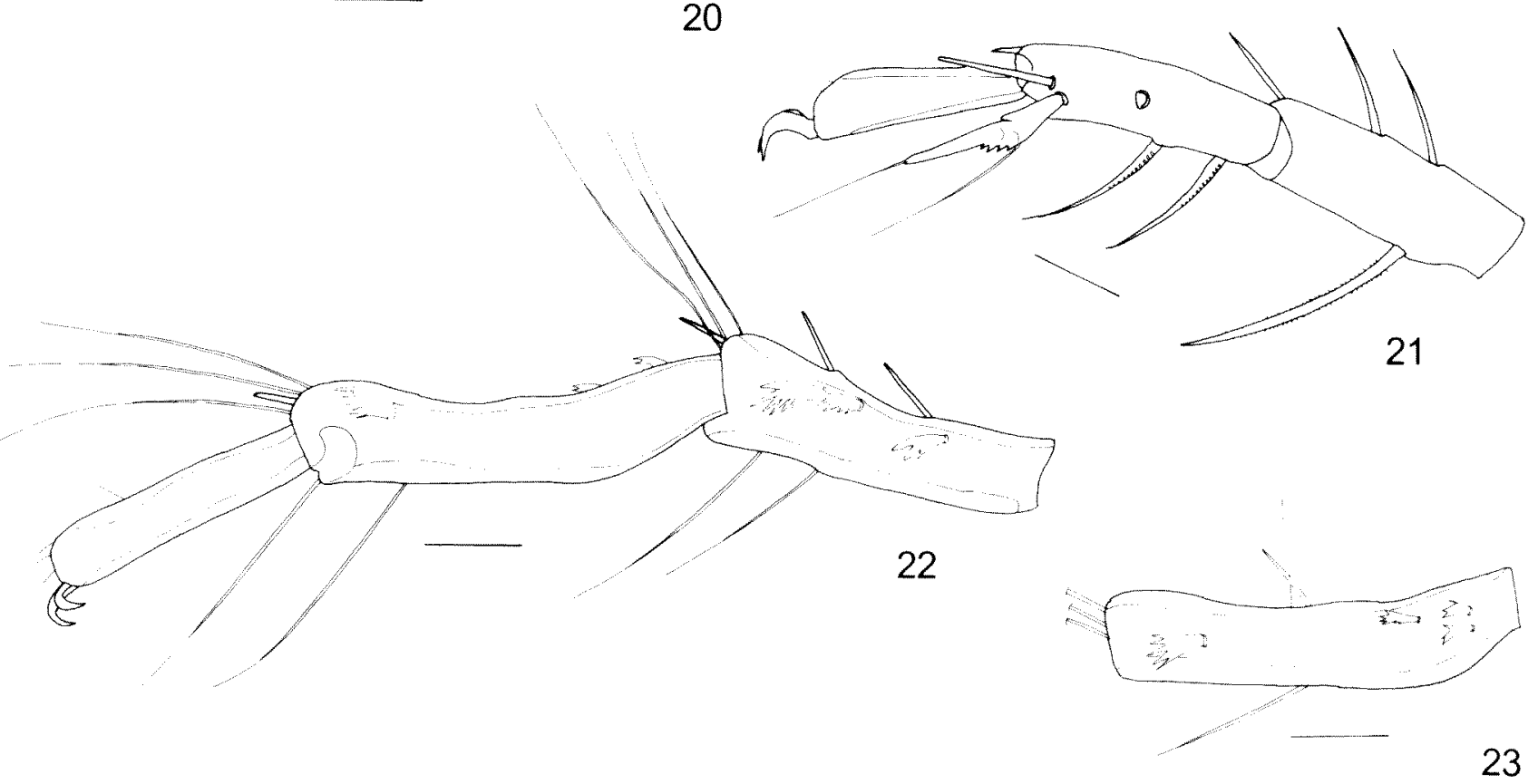

Figures 17-23 Recifella emma sp. nov: 17- 21 holotype male: 17, idiosoma, ventral view; 18, dorsal shield, 19, left palp; 20, I-leg-4-6; 21, III-leg-4-6;22, IV-leg-4-6; 23, IV-leg-5, ventral view. Scale lines: 50 um (Figures 17, 19-23), $200 \mu \mathrm{m}$ (Figure 18).

\section{Diagnosis}

IV-leg-5 of male with four specialised setae with small pectinations; distal heavy seta of this segment strongly bowed; distal heavy seta of III-leg-5 not pectinate.

\section{Description}

Male

Idiosoma 476 long and 437 wide. Dorsal shield 437 long and 365 wide with four pairs of 


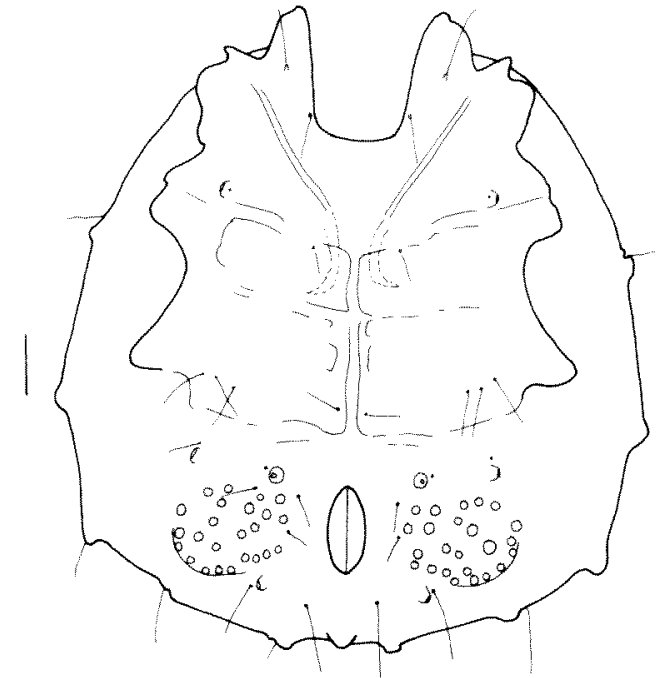

24
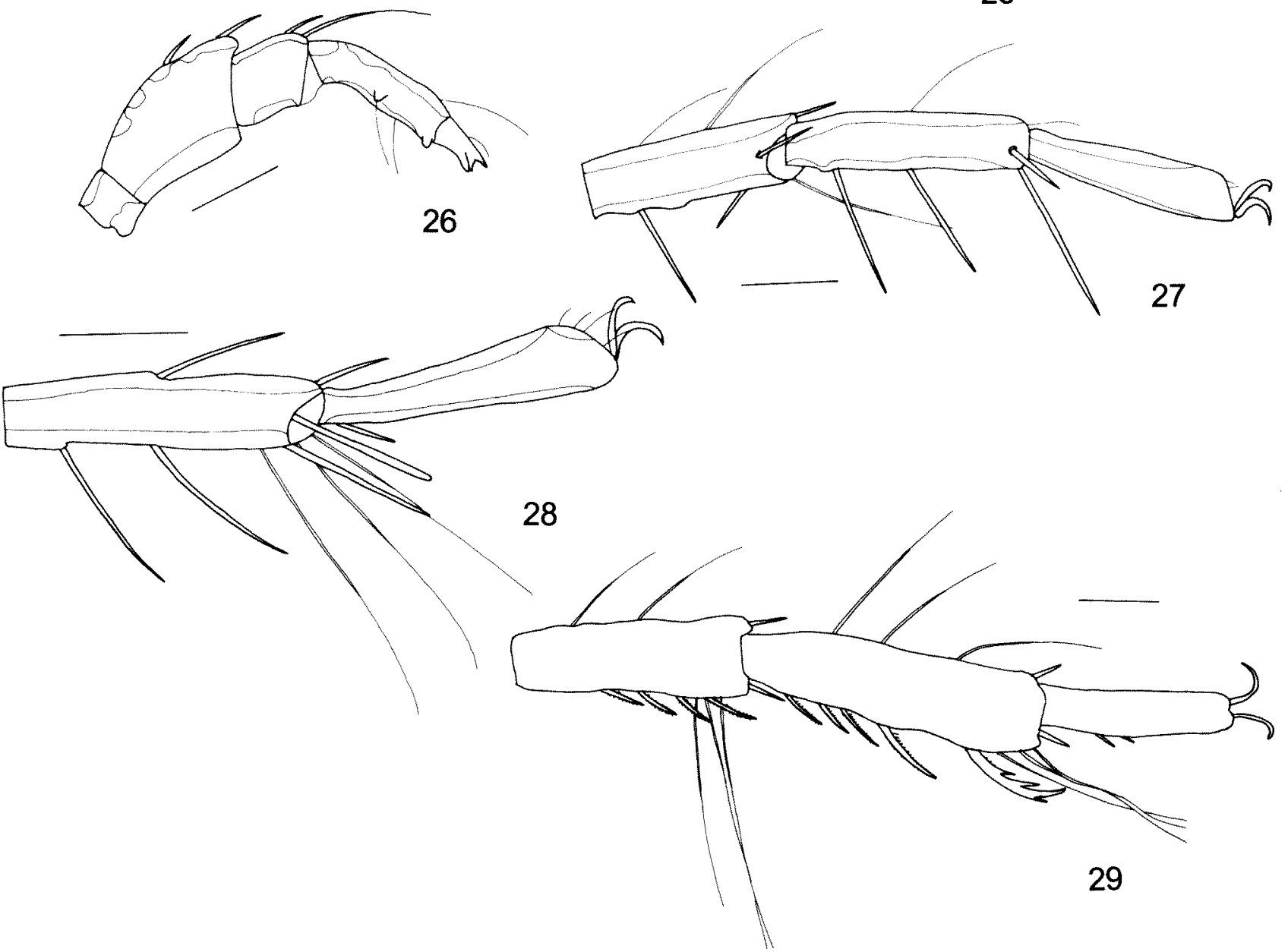

Figures 24-29 Recifella kakadu sp. nov.: 24-29, holotype male: 24, idiosoma, ventral view; 25, dorsal shield; 26, left palp; 27, I-leg-4-6; 28, III-leg-5-6; 29, IV-leg-4-6. Scale lines: $50 \mu \mathrm{m}$ (Figures 24-29).

glandularia, the two posterior pairs on small tubercles. Dorsal shield lightly fused posteriorly with ventral shield. Apodemes of anterior coxal plates extending to middle of third coxal plates. Genital field with approximately 25-26 pairs of acetabula. Gonopore 70 long. Lengths of PI-PV: 20 , $54,36,82,30$. Lengths of I-leg-4-6: 112, 124, 100.
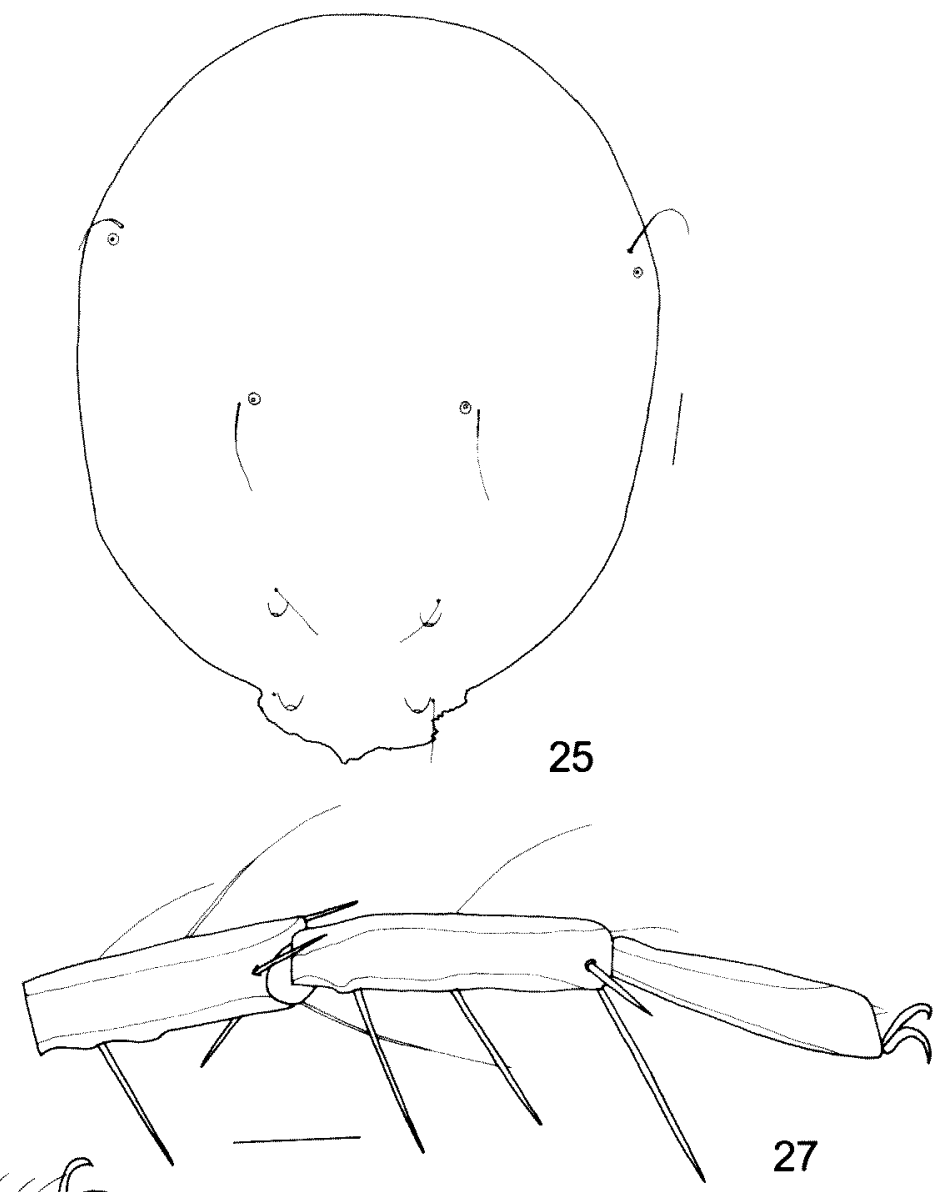

Distal heavy seta of III-leg-5 without pectinations and with a blunt distal end. Lengths of IV-leg-4-6: $144,184,124$. IV-leg-4 with three setae with small pectinations and a distally placed seta with large pectinations. IV-leg-5 with five setae, the posterior four are the so called specialized setae (sensu Cook 1986) with small pectinations, the most anterior one 
bowed and with large pectinations. III-leg-5, IV-leg4 and -5 with three swimming setae. First two legs without true swimming setae, but with stiff setae.

Fenlale

Unknown.

\section{Etymology}

This species is named after Kakadu National Park, and the name is a noun in apposition.

\section{Remarks}

The new species differs from all other species of the subgenus Recifellida in the presence of five pectinate setae on IV-leg-5, the distal seta strongly bowed with large pectinations. All other species of the subgenus have IV-leg-5 with four pectinate setae.

\section{Recifella (Recifellida) kimberleyensis sp. nov.}

Figures $30-36$

\section{Material examined}

Holotype

Australia: Western Australia: $\delta$, pool Silent Grove (behind ranger station), The Kimberley, 11 September 1998 (WAM T73163).

\section{Paratypes}

Australia: Western Australia: $2 \delta, 4 q$, same data as holotype (WAM T73164 [slide], WAM T73165 [tube]); 20,3 , same data as holotype (ZMAN TYPE ACAR.0007.1-5); 7 \%, 5 , pool near Adcock Gorge, The Kimberley, 12 September 1998 (ZMAN TYPE ACAR.0007.6).

\section{Diagnosis}

Middle of specialized setae of IV-leg-5 of male blade-like.

\section{Description}

Male

Idiosoma 551 (482-591) long and 502 (470-535) wide. Dorsal shield 506 long and 441 wide with four pairs of glandularia. Dorsal shield lightly fused posteriorly with ventral shield. Apodemes of anterior coxal plates extending to middle of third coxal plates. Genital field with approximately 21 pairs of acetabula. Gonopore 70 long. Lengths of PI-PV: 25, 80, 50, 96, 32. Lengths of I-leg-4-6: 172, 198, 188. Lengths of IV-leg-4-6:202, 259, 174. III-leg5 distally with a large pectinate seta. Both IV-leg-4 and IV-leg-5 with an S-shaped ventral margin. IVleg-5 with three specialized setae, the proximal and distal setae with large pectinations, the middle seta blade-like, all placed in the proximal half of the segment. Distal heavy seta of IV-leg-4 with small pectinations, the heavy seta in the middle of this segment with large pectinations. III-leg-5 with three swimming setae, IV-leg-3 with one swimming seta, IV-leg-4 with three swimming setae and IV-leg-5 with five swimming setae. Swimming setae of IVleg-4 abruptly thickened at base. Excretory pore terminal.

Female

Idiosoma 608 (591-620) long and 551 (559-571) wide. Dorsal shield separated from ventral shield, 559 long and 494 wide with three pairs of glandularia. One pair of glandularia in the dorsal furrow posteriorly of dorsal shield. Apodemes of anterior coxal plates reaching halfway third coxal plates. Genital field with numerous (> 25 pairs) acetabula. Gonopore 130 long. Lengths of PI-PV; $22,82,40,96,29$. Lengths of I-leg-4-6: 148, 170, 136. Lengths of IV-leg-4-6: 176, 214, 174. III-leg-4 and -5 and IV-leg-4 and -5 with three swimming setae. IVleg-6 with one pectinate seta, IV-leg-5 with 4 and IV-leg-4 with 3 pectinate setae. III-leg-5 with one distal pectinate seta. Excretory pore halfway between genital field and posterior idiosoma margin.

\section{Etymology}

Named after its occurrence in the Kimberley.

\section{Remarks}

The new species is most closely related to $R$. bifida Cook. However, the middle of the three specialised setae of IV-leg-5 of this species is bifid, IV-leg-4 is shorter with a less pronounced S-shaped ventral margin, the heavy seta in the middle of IVleg-4 has small pectinations (large pectinations in the new species) while the distal heavy seta of IVleg-4 has large pectinations (small in the new species).

\section{Recifella (Recifellida) ligulifera sp. nov. Figures $37-43$}

\section{Material examined}

\section{Holotype}

Australia: Northern Territory: $d$, pools upstream of Waterfall Creek, Kakadu National Park, $13^{\circ} 25^{\prime}$ 's, 132 25'E, 25 July 1994 (NTM A003763).

\section{Paratypes}

Australia: Northern Territory: 1 , same data as holotype (NTM A003764);

1 , same data as holotype (ZMAN TYPE ACAR.0008.1); Western Australia: 1 c, pool, Amalia Gorge, El Questro Station, The Kimberley, 16 September 1998 (WAM T73170). 


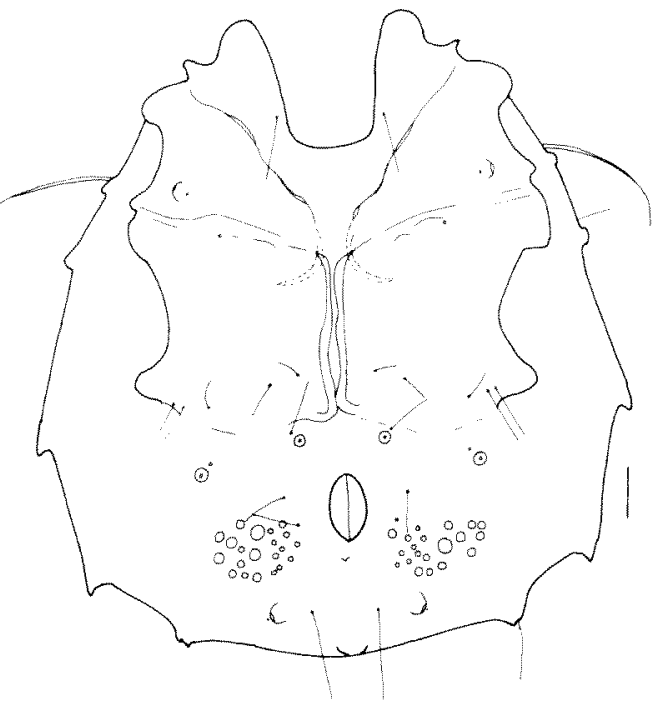

30

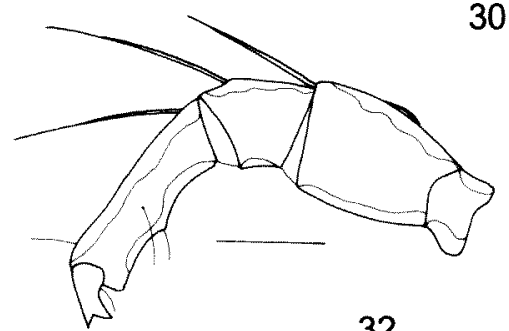

32
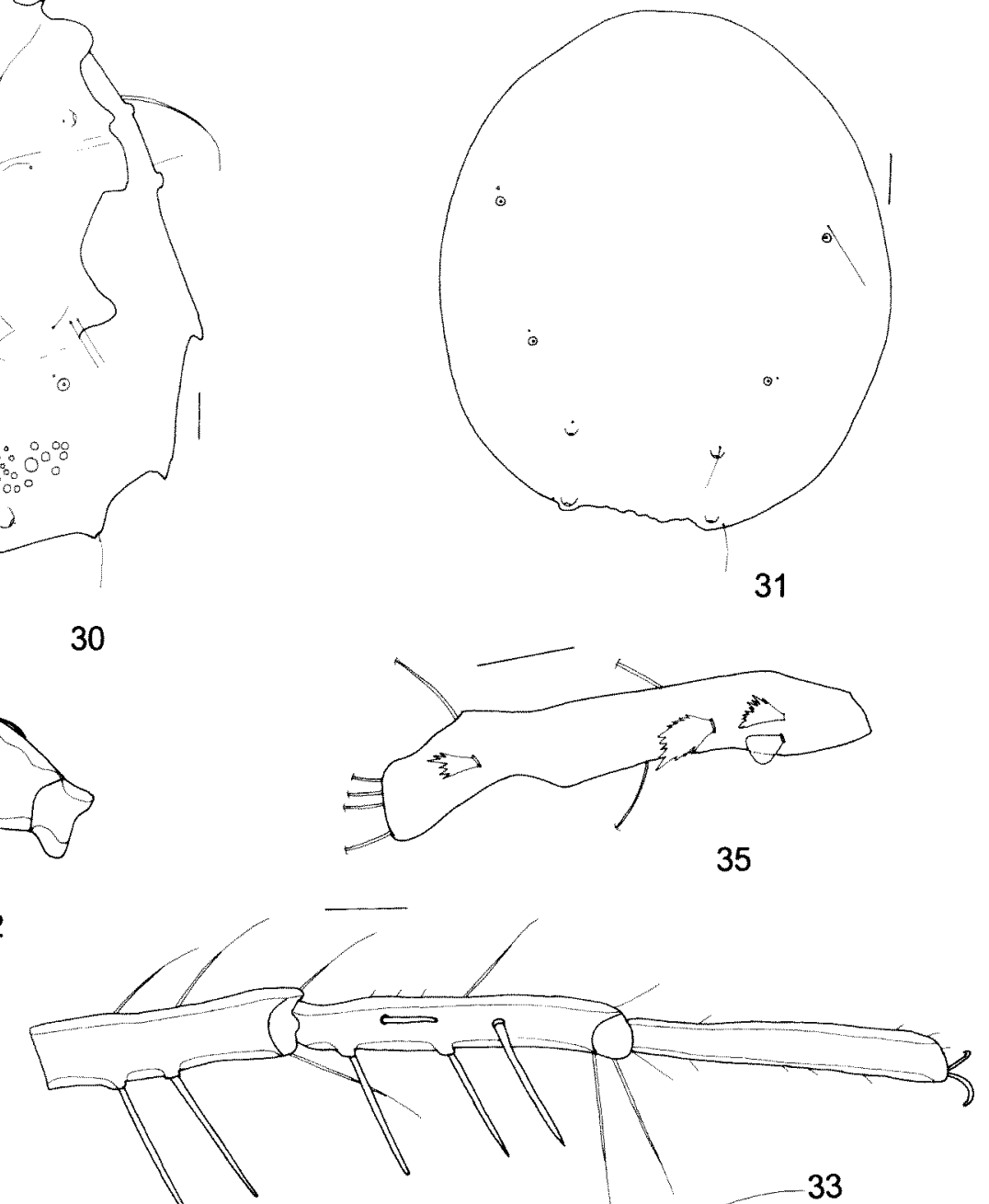

35

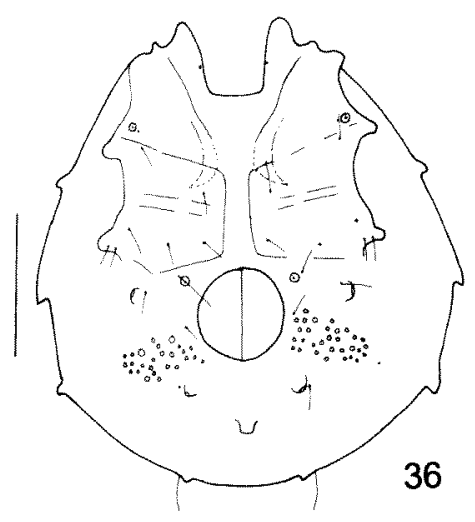

Figures 30-36 Recifella kimberleyensis sp. nov.: 30-35, holotype male: 30, idiosoma, ventral view; 31, dorsal shield; 32 , right palp; 33, I-leg-4-6; 34, IV-leg-4-6; 35, IV-leg-5, ventral view; 36, paratype female: 36, idiosoma, ventral view. Scale lines: $50 \mu \mathrm{m}$ (Figures 30-35); $200 \mu \mathrm{m}$ (Figure 36).

\section{Diagnosis}

IV-leg-5 of male with one spoon-shaped specialized seta in proximal part.

\section{Description}

\section{Male}

Idiosoma 551 (583) long and 510 (559) wide. Dorsal shield 535 long and 446 wide with four pairs of glandularia, lightly fused posteriorly with ventral shield. Apodemes of anterior coxal plates reaching to anterior part of third coxal plates. Genital field with numerous ( $>30$ pairs) acetabula. Gonopore 66 long. Lengths of PI-PV: 24, 103, 48, 90, 23. Lengths of I-leg-4-6: 121, 158, 132; heavy seta of first leg relatively short. Lengths of IV-leg-4-6: 156, 227, 187. In proximal part of IV-leg- 5 only one, spoon-shaped seta with anterior margin very finely serrated. In the distal part of IV-leg-5 four pectinate setae, the most distal seta with large pectinations, the other 

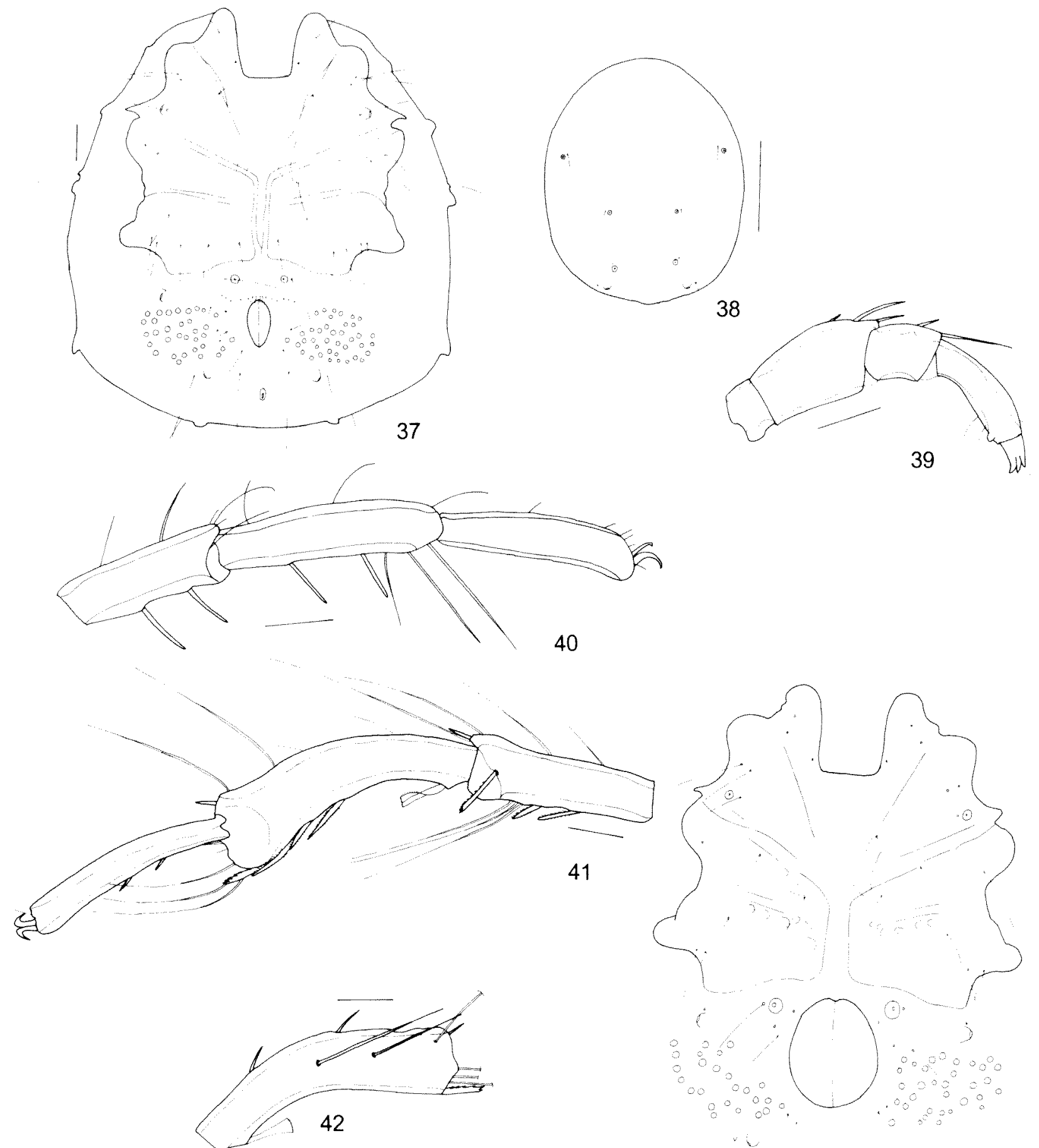

42

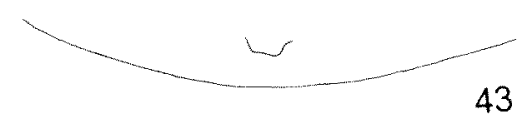

Figures 37-43 Recifella ligulifera sp. nov:: 37-42, holotype male: 37, idiosoma, ventral view; 38, dorsal shield; 39, left palp; 40, I-leg-4-6; 41, IV-leg-4-6; 42, IV-leg-5; 43, paratype female: 43, idiosoma, ventral view. Scale lines: $50 \mu \mathrm{m}$ (Figures 37, 39-43), $200 \mu \mathrm{m}$ (Figure 38).

three setae with small pectinations. Ventral margin of III-leg-5 with a distal seta with large pectinations and three setae without pectinations. IV-leg-4 and 5 with five and three swimming setae respectively, III-leg-4 and -5 with three swimming setae and Ileg-5 and II-leg-5 with two swimming setae.
Excretory pore halfway between genital field and posterior idiosoma margin.

\section{Female}

Idiosoma 680 (656) long and 577 (567) wide. Dorsal shield 616 long and 504 wide with four pairs 

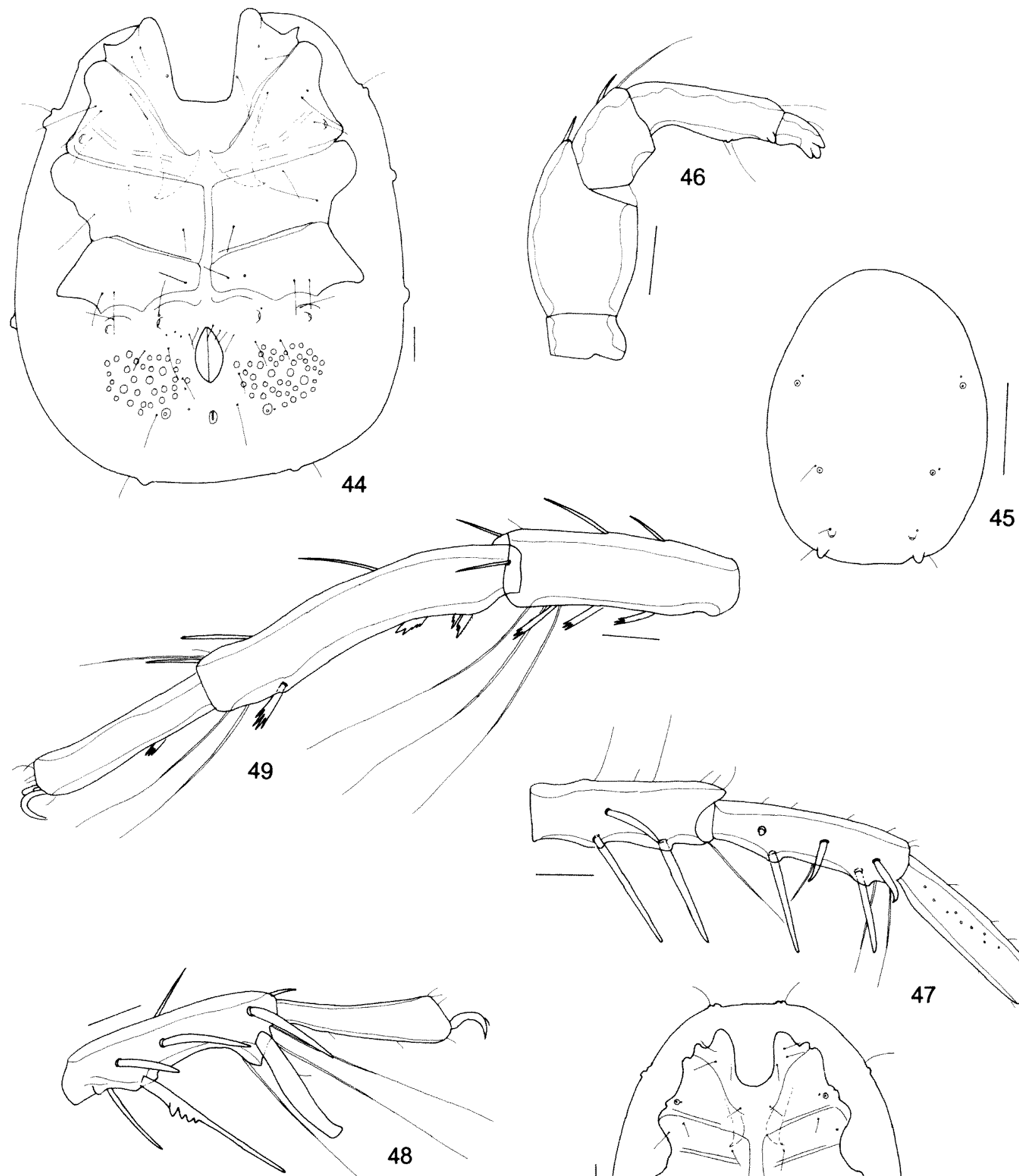

49

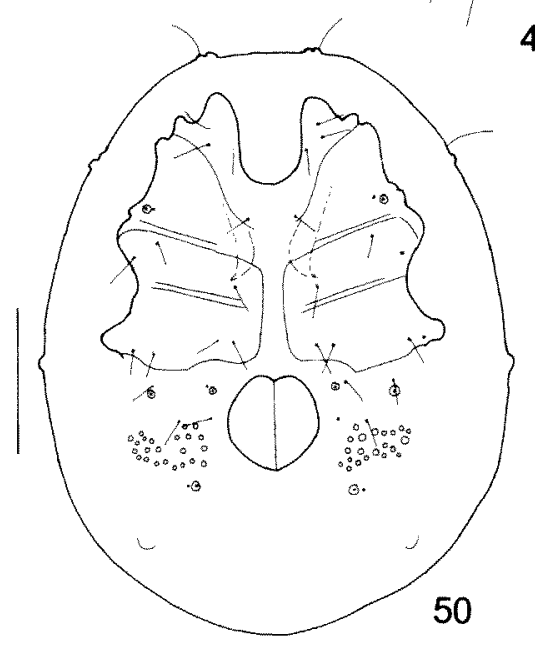

47

Figures 44-50 Recifella ornata sp. nov.: 44-49, holotype male: 44, idiosoma, ventral view; 45, dorsal shield; 46, left palp; 47, I-leg-4-6; 48, III-leg-5-6; 49, IV-leg-4-6; 50, paratype female: 50, idiosoma, ventral view. Scale lines: $50 \mu \mathrm{m}$ (Figures 44, 46-49), $200 \mu \mathrm{m}$ (Figures 45, 50). 
of glandularia, completely separated from ventral shield. Dorsal furrow without glandularia. Apodemes of anterior coxal plates reaching halfway of third coxal plates. Genital field with numerous $>$ 25 pairs) acetabula. Gonopore 116 long. Lengths of PI-PV: 24, 94, 46, 88, 26. Lengths of 1-leg-4-6: 112, 133, 108. Lengths of IV-leg-4-6: 156, 198, 170. Swimming setae as in male. Excretory pore subterminal.

\section{Etymology}

Named after the spoon-shaped seta of IV-leg-5.

\section{Remarks}

The peculiar spoon-shaped seta of IV-leg-5 will easily separate the new species from other species of the subgenus. The female shares the short setae of the first leg.

\section{Recifella (Recifellida) ornata sp. nov.}

Figures 44-50

\section{Material examined}

\section{Holotype}

Australia: Western Australia: $\delta$, pool Valentine Springs, W. of Kununurra, 18 September 1998 (WAM T73166).

\section{Paratype}

Australia: Western Australia: 19 , same data as holotype (WAM T73167).

\section{Diagnosis}

III-leg-5 of male with two modified setae, one heavy distal seta, somewhat bowed distally and truncated, and a sword-like seta with three large and one small teeth proximally.

\section{Description}

\section{Male}

Idiosoma 656 long and 543 wide. Dorsal shield 624 long and 478 wide with four pairs of glandularia, the two posterior pairs on small tubercles. Dorsal shield lightly fused posteriorly with ventral shield. Apodemes of anterior coxal plates reaching to anterior part of third coxal plates. Medial margin of third coxal plates longer than medial margin of fourth coxal plates. Genital field with numerous ( $>30$ pairs) acetabula. Gonopore 80 long. Lengths of PI-PV: 30, 122, 53, 132, 38; ventral margin of PII convex. Lengths of Ileg-4-6: 165, 164, 140; first leg with long heavy setae. Lengths of III-leg-4-6: 178, 190, 126. III-leg-5 with two modified setae, one heavy distal seta, somewhat bowed distally and truncated, and a sword-like seta with three large and one small tooth proximally. Lengths of IV-leg-4-6: 198, 283, 162. IV-leg-5 slightly bowed, with three setae with large pectinations in proximal half. III-leg-4 and -5 with three swimming setae, IV-leg-3 with one, IVleg-4 with 4 (one lost?) and IV-leg-5 with three swimming setae. First and second leg with rudimentary swimming setae: I-leg-4 with one and I-leg-5 and II-leg-5 with two such setae. Excretory pore closer to gonopore than to posterior idiosoma margin.

\section{Female}

Idiosoma 741 long and 595 wide. Dorsal shield with three pairs of glandularia, 680 long and 595 wide, completely separated from ventral shield. Posterior of dorsal shield a pair of glandularia in dorsal furrow. Apodemes of anterior coxal plates reaching halfway third coxal plates. Genital field with numerous ( $>20$ pairs) acetabula. Gonopore 138 long. Lengths of PI-PV: 25, 92, 54, 98, 30; palp as in male. Lengths of I-leg-4-6: 134, 140, 110. Lengths of IV-leg-4-6: 180, 211, 162. Swimming setae as in male. Excretory pore closer to gonopore than to posterior idiosoma margin.

\section{Etymology}

Named after the unusual setae of III-leg-5.

\section{Remarks}

The unusual modified setae of III-leg- 5 will easily separate the new species. Cook (1986) already noted that the third leg exhibits a certain degree of sexual dimorphism. In the new species the third leg is highly modified, more than in any other known species.

\section{Recifella (Recifellida) pseudoszalayi sp. nov.} Figures 51-58

\section{Material examined}

\section{Holotype}

Australia: Western Australia: $\delta$, Middle Springs W. of Kununurra, 18 September 1998 (WAM T73168).

\section{Paratypes}

Australia: Western Australia: 1 o, 1 , same data as holotype (ZMAN TYPE ACAR.0009.1-2); 1 , same data as holotype (WAM T73169); 1 , pool Amalia Gorge, El Questro Station, The Kimberley, 16 September 1998 (ZMAN TYPE ACAR.0009.3)

\section{Diagnosis}

Distal seta of $111-\operatorname{leg}-5$ of male with large pectinations, IV-leg-4 of male with distally a small, enlarged seta. 

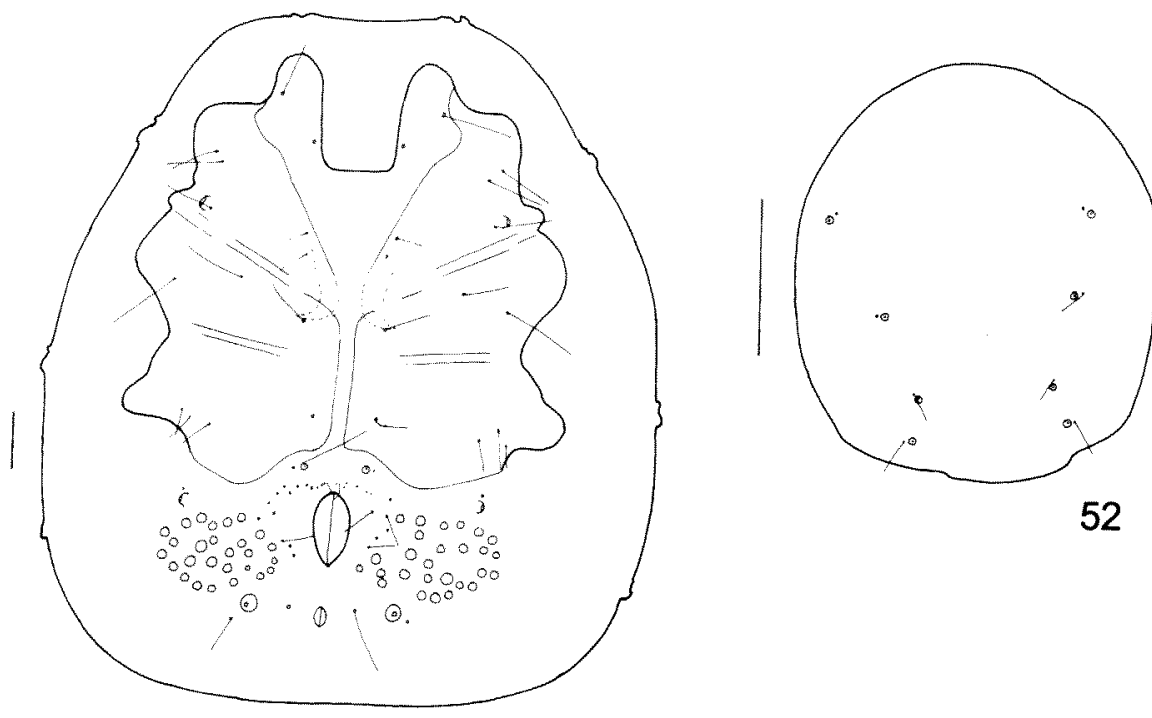

51

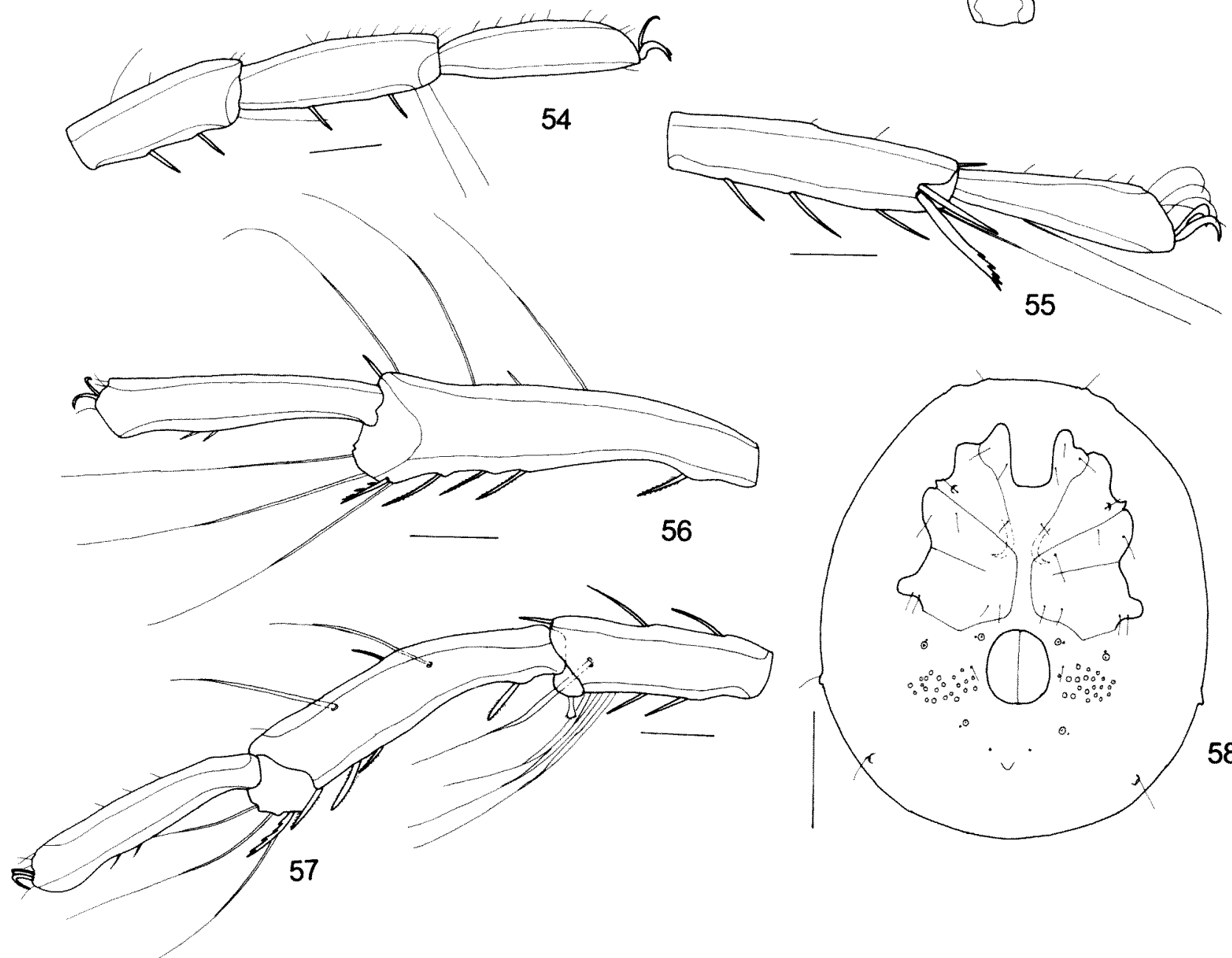

52
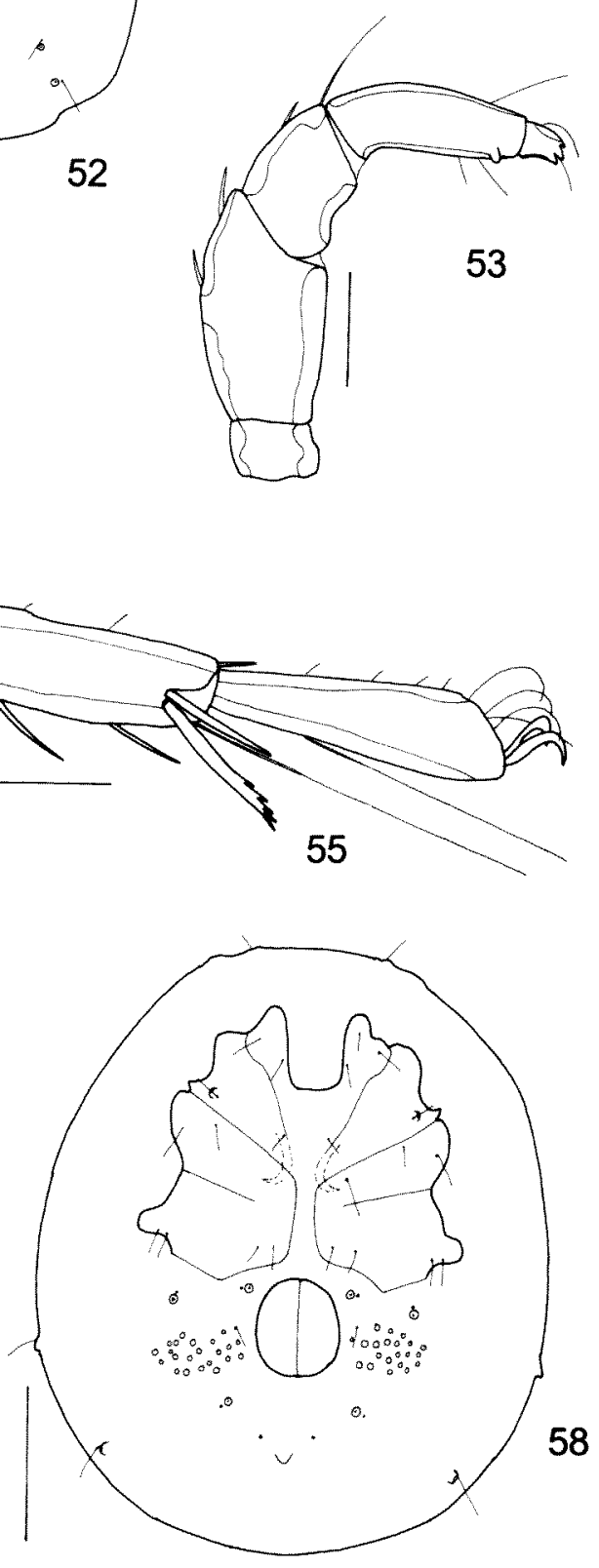

Figures 51-58 Recifella pseudoszalayi sp. nov.: 51-55, 57, holotype male; 56, paratype male: 51, idiosoma, ventral view; 52, dorsal shield; 53, left palp; 54, I-leg-4-6; 55, III-leg-5-6; 56, IV-leg-5-6; 57, IV-leg-4-6; 58, paratype female: 58, idiosoma, ventral view. Scale lines: $50 \mu \mathrm{m}$ (Figures 51, 53-57), $200 \mu \mathrm{m}$ (Figures 52, 58). 


\section{Description}

Male

Idiosoma 535 (502-527) long and 510 wide (437473). Dorsal shield 527 long and 462 wide with four pairs of glandularia, lightly fused posteriorly with ventral shield. First coxal plates not reaching to anterior idiosoma margin. Apodemes of anterior coxal plates reaching to anterior part of third coxal plates. Genital field with numerous ( $>25$ pairs) acetabula. Gonopore 62 long. Lengths of PI-PV: 24, 101, 54, 84, 19; PIV and PV stocky. Lengths of I-leg-4-6: 128, 139, 118. Heavy setae of first leg short. Distal heavy seta of III-leg-5 with large pectinations. Lengths of IV-leg-4-6: $152,227,154$. IV-leg-5 slightly bowed, with four specialized setae: one seta with small pectinations in proximal half of segment, three setae with large pectinations in distal part of segment. IV-leg-5 dorsally with three long setae, these better visible in illustration of the paratype (see fig. 56). IV-leg-4 distally with a small distally enlarged seta instead of the usual large seta with heavy pectinations. I-leg-4 and I-leg-5 with one respectively two reduced swimming setae, II-leg-4 and II-leg-5 with respectively 1 and two swimming setae, III-leg-3, III-leg-4 and IIIleg-5 with respectively one, three and three swimming setae, IV-leg-3, IV-leg-4 and IV-leg-5 with respectively one, five and three swimming setae.

\section{Female}

Idiosoma 747 (729) long and 659 (648) wide. Dorsal shield with four pairs of glandularia, 721 long and 527 wide, completely separated from ventral shield. Dorsal furrow without glandularia. Apodemes of anterior coxal plates extending to middle of third coxal plates. Genital field with numerous ( $>20$ pairs) acetabula. Length of gonopore not measurable. Tubercles associated with glandularia small and hardly extending beyond idiosoma margin. Lengths of PI-PV: 26, 90, $46,80,24$; palp as in male. Lengths of I-leg-4-6: 112, 120, 98; heavy setae small. Lengths of IV-leg-4-6: $160,198,154$. Swimming setae as in male.

\section{Etymology}

Named for its similarity with $R$. szalayi Cook.

\section{Remarks}

The new species is similar to $R$. szalayi Cook in a number of characters. The first leg has the same chaetotaxy, and also IV-leg-5 is similar. Differences are found in III-leg-5, which has a seta with large pectinations (without pectinations in $R$. szalayi), and in IV-leg-4 which has a small seta enlarged distally (large seta with small pectinations in $R$. szalayi). Moreover, III-leg- 6 has three long seta dorsally, which are absent in the new species. Instead, $R$. pseudoszalayi sp. nov. has a number of fine, curved setae dorsodistally.

\section{Recifella (Recifellida) szalayi Cook}

Recifella (Recifellida) szalayi Cook, 1986: 173; Harvey, 1998: 143.

\section{Material examined}

Australia: Queensland: 1 o, Fitzroy River, 30 August 1983, coll. A.P. Mackay; 1 o, Fitzroy River, Yaamba, 20 February 1984, A.P. Mackay; 1 o, 5 , , Hann Crossing (stagnant), Lakefield National Park, 4 September 2000. Western Australia: 1 o, Cockatoo Creek at crossing with Great Northern Highway, 8 September 1998 (WAM T66733). Northern Territory: 1 o, 4 o, 17 Mile Creek, tributary of Katherine River, Katherine Gorge National Park, 28 July 1994.

\section{Remarks}

Previously only reported from Queensland, and reported here for the first time from Western Australia.

\section{Recifella (Recifellida) tinka (K.O. Viets)}

Koenikea tinka K.O. Viets, 1975: 100.

Recifella (Recifellida) tinka (K.O. Viets): Smit, 1992: 101; Harvey, 1998: 143.

\section{Material examined}

Australia: Western Australia: $2 \hat{0}, 1 q$, pond, Kalamina Gorge (near falls), Hamersley Range National Park, 13 August 1994; 1 ઈ, 2 \%, small pond near Crossing Pool, Millstream-Chichester National Park, 16 August 1994; 1 o, 1 \&, Python Pool, Millstream-Chichester National Park, 17 August 1994; 5 \%, 9 , pond in Jones River, E. of Roeburne, 17 August 1994 (WAM T66734); 4 ठ。, 30 $q$, pond Snake Creek, Millstream-Chichester National Park, 17 August 1994; 2 o, 5 q, Moore River, at crossing with Brandt's Highway, Regans Ford, 26 August 1994; 1 \$, 1 \% , Cockatoo Creek at crossing with Great Northern Highway, 8 September 1998; $1 \mathrm{~d}$, pools $3 \mathrm{~km}$ from Lennard Gorge, The Kimberley, 10 September 1998; 1 t, pool Lennard Gorge, The Kimberley, 10 September 1998; 3 o , 9 \% , Spillway Creek near Lake Argyle, 20 September 1998 (WAM T66735); 20,4 o, pools in creek at Old Halls Creek, S. of Halls Creek, 26 September 1998; $10 \hat{0}, 28$, pool W. of Tunnel Creek, Tunnel Creek National Park, 30 September 1998; 1 o, 2 o, unnamed creek at crossing with Windjana Gorge Road, $38 \mathrm{~km}$ N. of Great Northern Highway, 30 September 1998. Northern Territory: 8 đ, 9 \&, Manton Dam, 1 August 1994.

\section{Remarks}

Previously reported from two locations in Queensland, and reported here for the first time for Western Australia and Northern Territory. From 
this study it can be concluded that the species is much more common in western Australia than in eastern Australia.

\section{Recifella (Recifellida) umala Cook}

Recifella (Recifellida) umala Cook, 1986: 181; Harvey, 1998: 143.

Material examined

Australia: New South Wales: $2 \delta, 15$ ㅇ, Wheeny Creek at crossing with Comleroy Road, Wollemi National Park, 1 December 2003; 7 đo, 40 ㅇ, 6 nymphs, Colo River at crossing with Putty Road, 33²5.959'S, $150^{\circ} 49.688^{\prime} \mathrm{E}, 1$ December 2003.

\section{Recifella (Recifellida) vonjama Cook}

Recifella (Recifellida) vonjama Cook, 1986: 176; Harvey, 1998: 143.

\section{Material examined}

Australia: Tasmania: $1 \delta, 3 q$, Apsley River at crossing with Tasmanian Highway, 19 October 1997. New South Wales: 10 , Bombala River at crossing with New Line Road, $36^{\circ} 42.402^{\prime} \mathrm{S} 149^{\circ} 23.688^{\prime} \mathrm{E}$, altitude $782 \mathrm{~m}$ a.s.l., 11 December 2003.

\section{Remarks}

Previously reported from two locations in Tasmania and one location in New South Wales. Cook's specimens measure 669-684 in length, the males from this study are smaller and measure 599616 in length.

\section{Key to the Australian Recifella species}

Recifella colorata (K.O. Viets, 1980) is not included in this key as it is only known from the female. Cook (1986) pointed out the heavy setae of PV as a distinguishing character. However, this character can be found in other species, and $R$. colorata has no other characters to make a correct identification possible. Collection of more material on the type locality could perhaps solve this problem.

1. Palp large and stocky, PII with a large heavy seta (figure 3)

Palp slender, PII without heavy seta ................. 3

2. PIV and PV stocky (PV as large as wide), PIV ventrally with a very large setal tubercle $R$. crassipalpis sp. nov.

PIV and PV less stocky (PV longer than wide), PIV ventrally with smaller tubercles and distally a recurved seta (figure 16)

$$
R \text {. pinguipalpifera Wiles }
$$

3. Postocularia and glandularia 2 in dorsal furrow near eyes (figure 10) ... R. hyporheica sp. nov.
Postocularia and glandularia not located in dorsal furrow near eyes.

4. PIV with a long dorsodistal seta (Cook 1986, figure 907) R. flagellata Cook

PIV without long dorsodistal seta 5

5. Fourth leg not exhibiting sexual dimorphism in male, females with dorsal shield with three pairs of glandularia and without glandularia in dorsal furrow posterior of dorsal shield (Cook 1986, figures 899, 901) ...........R. australica Cook

Fourth leg exhibiting sexual dimorphism in male, females either with four pairs of glandularia on dorsal shield, or dorsal shield with three pairs of glandularia and with glandularia in dorsal furrow posterior of dorsal shield (following part based on males only)

... 6

6. Distal heavy seta of III-leg-5 without pectinations (figure 48) 7

Distal heavy seta of III-leg-5 with pectinations (figure 21) 9

7. Heavy distal seta of III-leg-5 truncated $R$. ornata sp. nov.

Heavy distal seta of III-leg-5 not truncated (Cook 1986, figure 921) ... 8

8. Heavy distal seta of III-leg-5 broad and distally pointed R. szalayi Cook

Heavy distal seta of III-leg-5 slender and distally blunt (figure 28) .. R. kakadu sp. nov.

9. Tips of first coxal plates narrow and sharply pointed (Cook 1986, figure 909)

R. plana Cook

Tips of first coxal plates broad and tend to be rounded. 10

10. Distal heavy seta of III-leg-5 with a few large teeth ventrally (figure 21) ... R. emma sp. nov.

Distal heavy seta of usual shape with pectinations along whole margin

11

11. Most proximal of specialized setae of IV-leg-5 spoon-shaped with margins finely serrated (Figure 42) $R$. ligulifera sp. nov.

Most proximal of specialized setae not spoonshaped 12

12. Specialized seta of IV-leg-5 located both in distal and proximal half of segment (Figure 57) 13

Specialized setae of IV-leg-5 located only in proximal half of segment 14

13. Proximal half of IV-leg-5 with one specialized seta, IV-leg-4 distally with a small seta enlarged distally (Figure 57) R. pseudoszalayi sp. nov. 
Proximal half of IV-leg-4 with at least two specialized setae, IV-leg-4 with a large pectinate seta (Cook 1986, figure 923).

R. doomba Cook

14. Two or all three of the specialized medial setae of IV-leg-5 relatively long and with small pectinations 15

All three of the specialized setae of IV-leg-5 relatively short and with large pectinations.. 17

15. The most distal of the three specialized setae of IV-leg-5 with large pectinations (Cook 1986, figure 930) R. vonjama Cook

All three specialised setae of IV-leg-5 with small pectinations 16

16. The three specialized setae of IV-leg-5 close together and located on a noticeable ventral bulge, heavy setae of III-leg-5 long (Cook 1986, figure 942) R. triradiata Cook

The three specialized setae of IV-leg-5 further apart on a slight ventral bulge, heavy setae of III-leg-5 comparatively short (Cook 1986, figure 945) R. baltoona Cook

17. The middle of the three specialized seta of IVleg-5 much shorter than the others and bifurcate (Cook 1986, figure 953) .... R. bifida Cook

The middle of the three specialized seta of IVleg-5 not noticeably shorter than the others and not bifurcate

18. Excretory pore terminal and projecting when seen in ventral view, smaller species $(<560$ $\mu \mathrm{m}$ ) (Cook 1986, figure 959)

R. agnosta Cook

Excretory pore subterminal and not projecting beyond the posterior margin of ventral shield, larger species (>590 $\mu \mathrm{m}$ ) (Cook 1986, figure 967) R. umala Cook

\section{ACKNOWLEDGEMENTS}

I am indebted to Owen Seeman (QM) for the loan of the holotype of $R$. pectinata. The national park authorities of Western Australia, the Northern Territory, Queensland, New South Wales, Victoria and Tasmania gave permission to collect in their national parks. Dr Terry Gledhill donated water mites collected by A.P. Mackay in the beginning of the 1980s. Truus van der Pal assisted me with the fieldwork, and Johannes Postma (Ann Arbor) reviewed the English.

\section{REFERENCES}

Boulton, A.J., Valett H.M. and Fisher S.G. (1992). Spatial distribution and taxonomic composition of the hyporheos of several Sonoran Desert streams. Archiv für Hydrobiologie 125: 37-61.

Cook, D.R. (1980). Studies on neotropical water mites. Memoirs of the American Entomological Institute 31: $1-645$.

Cook, D.R. (1986). Water mites from Australia. Memoirs of the American Entomological Institute 40: 1-568.

Harvey, M.S. (1998). The Australian Water Mites. A Guide to Families and Genera. Monographs on Invertebrate Taxonomy 4. CSIRO Publishing, Collingwood, $150 \mathrm{p}$.

Lundblad, O. (1943). Die Hydracarinenfauna Südbrasiliens und Paraguays. Dritter Teil. Kungliga Svenska Vetenskapsakademiens Handlingar (ser. 3) 20: 1-148.

Smit, H. (1992). Water mites from New South Wales and Queensland, Australia (Acari, Hydrachnellae). Tijdschrift voor Entomologie 135: 91-112.

Smit, H. (2002). Water mites from New Caledonia (Acari: Hydrachnidia). In: Najt, J. and Grandcolas P. (eds), Zoologia Neocaledonica 5 . Systématique et endémisme en Nouvelle-Calédonie. Memoirs du Muséum national d'Fistoire naturelle 187: 161-206.

Viets, K. (1935). Neue brasilianische Wassermilben. Zoologischer Anzeiger 112: 273-283.

Viets, K.O. (1975). Neue Wassermilben (Acari, Hydrachnellae) aus Australien. Zoologica Scripta 4: 93-100.

Viets, K.O. (1980). Weitere Wassermilben (Hydrachnellae, Acari) aus Australien. Gewässer und Abwässer 66/67: 143-169.

Wiles, P.R. (1997). The water mites (Acari: Hydrachuidia) of New Guinea. The Raffles Bulletin of Zoology 45: $275-418$.

Manuscript received 10 September 2005; accepted 21 March 2007 